University of Louisville ThinkIR: The University of Louisville's Institutional Repository

Electronic Theses and Dissertations

$5-2019$

\title{
Anthropogenic landscapes of Amazonia : a spatial analysis of landscape modification and settlement organization at Macurany, Brazil.
}

M. Grace Ellis

University of Louisville

Follow this and additional works at: https://ir.library.louisville.edu/etd

Part of the Archaeological Anthropology Commons, and the Geographic Information Sciences Commons

\section{Recommended Citation}

Ellis, M. Grace, "Anthropogenic landscapes of Amazonia : a spatial analysis of landscape modification and settlement organization at Macurany, Brazil." (2019). Electronic Theses and Dissertations. Paper 3169.

https://doi.org/10.18297/etd/3169

This Master's Thesis is brought to you for free and open access by ThinkIR: The University of Louisville's Institutional Repository. It has been accepted for inclusion in Electronic Theses and Dissertations by an authorized administrator of ThinkIR: The University of Louisville's Institutional Repository. This title appears here courtesy of the author, who has retained all other copyrights. For more information, please contact thinkir@louisville.edu. 


\title{
ANTHROPOGENIC LANDSCAPES OF AMAZONIA: A SPATIAL ANALYSIS OF LANDSCAPE MODIFICATION AND SETTLEMENT ORGANIZATION AT MACURANY, BRAZIL.
}

\author{
By \\ M. Grace Ellis \\ B.A., University of Louisville, 2013

\begin{abstract}
A Thesis
Submitted to the Faculty of the College of Arts and Sciences of the University of Louisville in Partial Fulfillment of the Requirements for the Degree of
\end{abstract}

Masters of Arts in Anthropology

\author{
Department of Anthropology \\ University of Louisville \\ Louisville, Kentucky
}

May 2019 
Copyright 2019 by M. Grace Ellis

All rights reserved 

ANTHROPOGENIC LANDSCAPES OF AMAZONIA: A SPATIAL ANALYSIS OF LANDSCAPE MODIFICATION AND SETTLEMENT ORGANIZATION AT MACURANY, BRAZIL.

\author{
By \\ M. Grace Ellis \\ B.A., University of Louisville, 2013 \\ A Thesis Approved on
}

April 1, 2019

by the following Thesis Committee:

Anna Browne Ribeiro

Jonathan Haws

Andrea Gaughan 


\section{ACKNOWLEDGEMENTS}

I would first like to express my gratitude to the community members of Parintins and professors from the Universidade do Estado do Amazonas who initiated the project. Without them, this thesis would not exist. A very special thank you to my advisor, Dr. Anna Browne Ribeiro, whose guidance, encouragement, conversation, and support were essential to the success of this thesis. Thank you to Dr. Filippo Stampanoni and Marta Cavallini for generously hosting us in Manaus during our field work and to Michel Carvalho for keeping things fun in the field! I would also like to thank Dr. Jonathan Haws, whom I conducted my first archaeological field school under and who has provided me with the opportunity to develop the spatial analysis skills required for this

project. Thank you to my parents, Dan and Lisa Gimbel, for instilling in me a passion and appreciation for archaeology at a young age and encouraging me to follow my dreams. Finally, to my wonderful husband Sam, thank you for being my constant confidant and companion, now and always. 


\section{ABSTRACT \\ ANTHROPOGENIC LANDSCAPES OF AMAZONIA: A SPATIAL ANALYSIS OF \\ LANDSCAPE MODIFICATION AND SETTLEMENT ORGANIZATION AT \\ MACURANY, BRAZIL.}

M. Grace Ellis

March 29, 2019

Traditional views of Amazonian habitation in the deep past revolve around environmental limitations on cultural development. This thesis challenges traditional perceptions of Amazonian societies as environmentally determined and adds to our understanding of ancient human occupation and modification of Amazonian landscapes. Anthropogenic landscapes are the product of complex human-environment processes that form distinct features in the landscape, which materially preserve and reflect human behavior. Anthropogenic landscapes in Amazonia likely date back to human colonization of the region around 16,000 BP. Since colonization, humans have been marking, modifying, managing, and engineering the landscape resulting in a mosaic of anthropogenic landscape features across Amazonia. The diversity of ancient landscapes documented in Amazonia reflects the cultural heterogeneity that existed in the past. This research explores the complex human-environmental processes that form distinct, identifiable, lasting features on the landscape and what these features can illuminate about past human behavior and human-environment interaction in Amazonia. Data for this research was collected by the Tupinambarana Project at the pre-Columbian site, 
Macurany, located along the Middle Amazon River in Parintins, Brazil. Survey and topography revealed four distinct classes of anthropogenic landscape features at the site, including ports, middens, terra preta, and cultural forests. These features are clearly the result of anthropogenesis and represent a range of subsistence, settlement, and infrastructure-building activities pointing to a society that was actively engaged with modifying the surrounding landscape. Geospatial analysis of the patterning of landscape features evidenced at Macurany suggest social organization was decentralized. The notion of a permanent, extensive, continuously settled, and decentralized society practicing intensive landscape engineering in pre-Columbian Amazonia challenges traditional perceptions of habitation density and early urbanization in Amazonia. This research contributes towards an understanding of human-environment interaction, landscape formation processes and urbanization in pre-Columbian Amazonia. 


\section{TABLE OF CONTENTS}

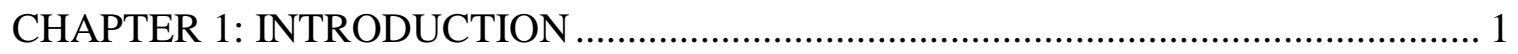

CHAPTER 2: CULTURAL GEOGRAPHIES OF AMAZONIA ……………………..... 4

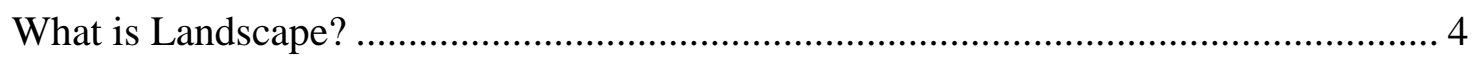

Landscape Archaeology ……………............................................................... 5

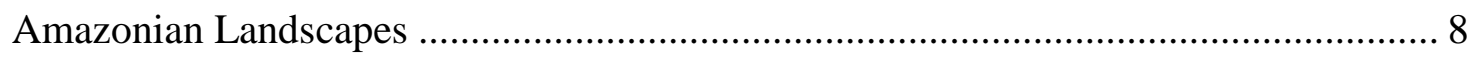

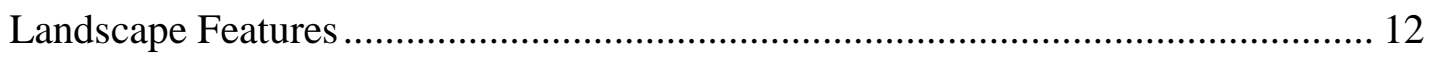

Ports and Anthropogenic Landscapes ................................................................. 21

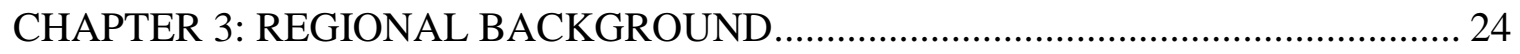

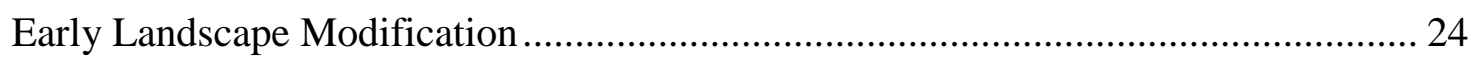

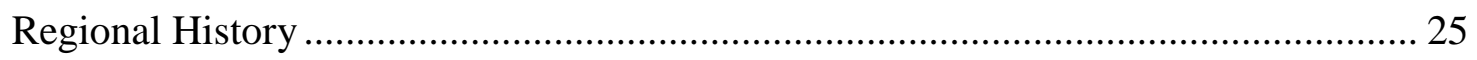

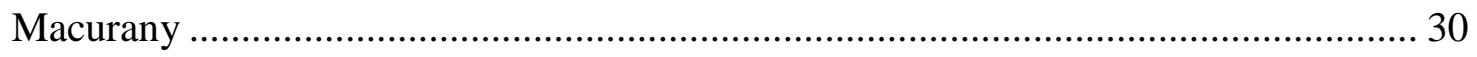

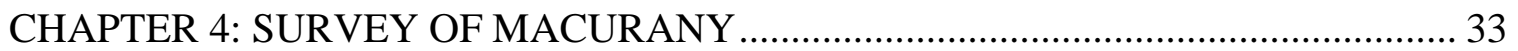

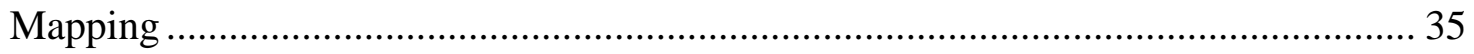

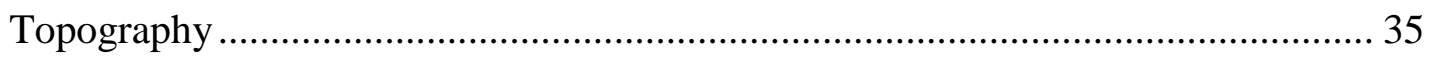

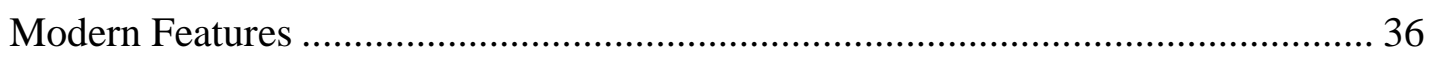

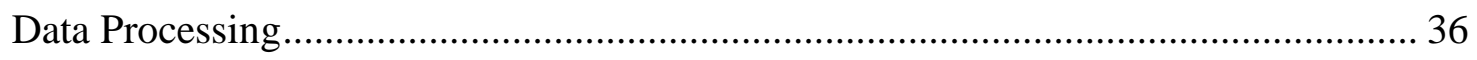

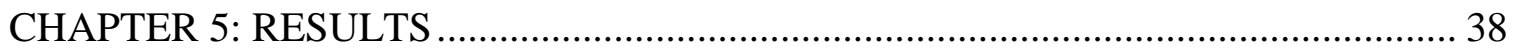

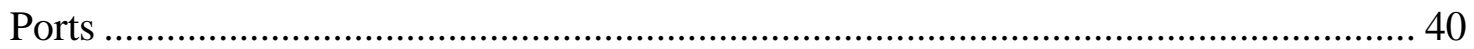

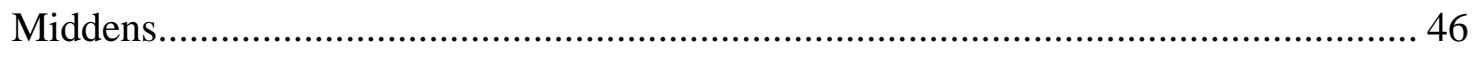

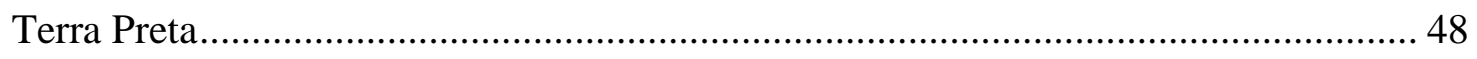

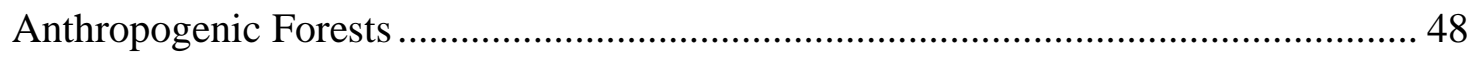

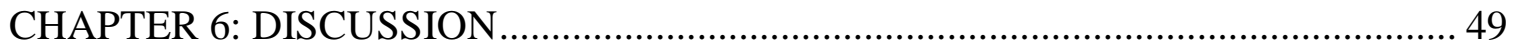

Spatial Patterning of Landscape Features ................................................................... 49

Landscape Formation Processes ………………….............................................. 50

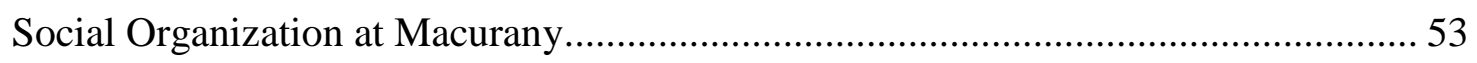

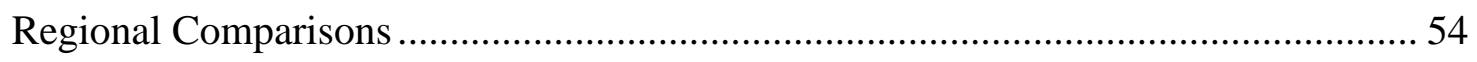

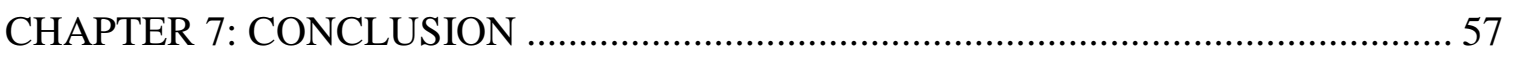




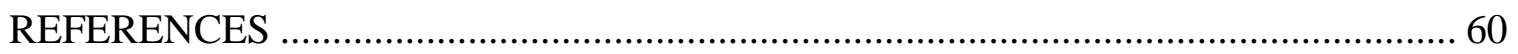

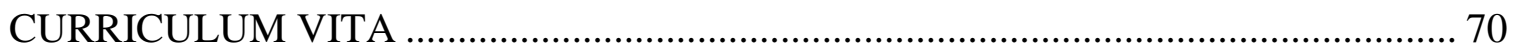




\section{LIST OF FIGURES}

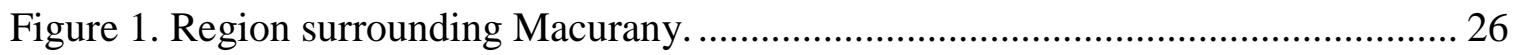

Figure 2. Location of Macurany. ............................................................................... 31

Figure 3. Extent of surveyed area at Macurany........................................................ 34

Figure 4. (A) Extent of topographically mapped area with 50cm contours. (B) Topography of middens and ports with $25 \mathrm{~cm}$ contours. (C) Topography of middens and

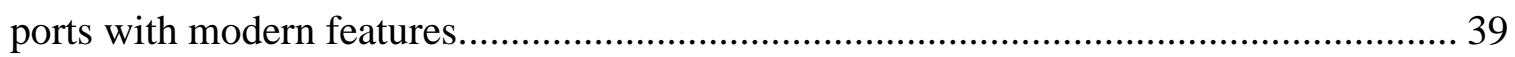

Figure 5. (A) Topography of ports at Macurany with 50cm contours. (B) Topography of ports at Macurany with $25 \mathrm{~cm}$ contour and modern features........................................... 40

Figure 6. Southwest view of Port 1 and garden on bluff. Photo taken by Anna Browne

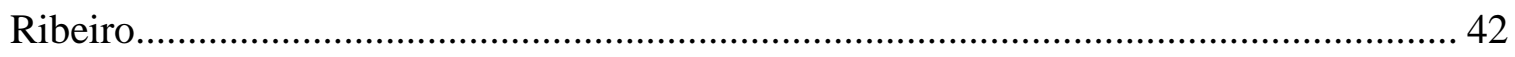

Figure 7. Northwest view of Port 1 from lakeshore. Photo taken by Anna Browne

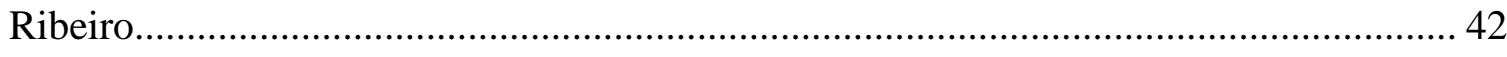

Figure 8. Southeast view of Port 2. Photo taken by Anna Browne Ribeiro. .................... 43

Figure 9. South view of Port 2 with house constructed on bluff. Photo taken by Anna

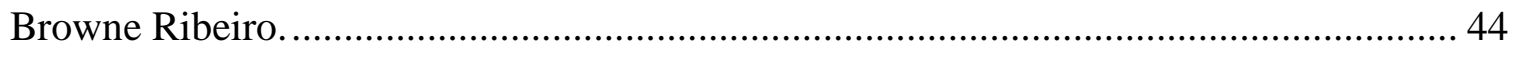

Figure 10. Southeast view of Port 3. Photo taken by Anna Browne Ribeiro. ................... 45

Figure 11. Northeast view of Port 3. Photo taken by Anna Browne Ribeiro. ................... 45

Figure 12. (A) Topography of middenscape at Macurany with $5 \mathrm{~cm}$ contours. (B)

Topography of middensacpe at Macurany with modern features...................................... 47 
Figure 13. Distribution of anthropogenic forests at Macurany................................... 48

Figure 14. Possible reconstruction of Macurany. ......................................................... 53 


\section{CHAPTER 1: INTRODUCTION}

Amazonia is an extremely heterogeneous landscape composed of a multitude of biomes, environmental niches and microhabitats, anthropogenic landscapes, and cultural forests. This description does not match the traditional picture of Amazonian landscapes as pristine forests and untouched Edens. However, this perception of Amazonia as "untouched" is beginning to change into what Amazonian archaeologists are calling a cultural mosaic: a complex landscape created by natural and cultural processes that have been in motion since human colonization of Amazonia. This research explores the complex human-environment processes that form distinct, identifiable, lasting features on the landscape and what these features can illuminate about past human behavior and human-environment interaction in Amazonia.

Landscape archaeologists strive to understand how meaning and culture are created, experienced, and reproduced in space. Landscapes are the products of interactions between communities and their surrounding environments that are temporally and geographically specific (Walker 2012). The fact that landscapes are defined by specific geographic areas and moments in time makes them important sources of information for archaeological investigation into human-environment interaction. Landscapes are created through the repeated performance of everyday activities and tasks (Ingold 1991), which eventually become materially preserved in the landscape forming 
distinct features. Through spatial analysis of ancient anthropogenic landscape features, patterns of tasks and activities can be identified, which can inform on landscape formation processes, social organization, and human-environment interaction in the past.

In this thesis, I analyze anthropogenic landscape features at Macurany, a preColumbian terra preta site on the Middle Amazon River in Parintins, Brazil, in order to gain insight into landscape formation processes and social organization. Data for this project was collected at Macurany in July 2017 as part of the Tupinambarana Project, an international collaboration between the University of Louisville, the Universidade do Estado do Amazonas, the Museu da Amazonia, and community members from Parintins. Survey and topographic mapping helped identify anthropogenic features at the site. Modern features were also mapped to identify any irregularities in the topography due to modern site use. Geospatial analysis of anthropogenic landscape features at Macurany, which include ports, middens, terra preta, and cultural forests, helped identify what processes contributed to the formation of these landscape features and how the spatial patterning of these features can illuminate aspects of social organization.

Anthropogenic earthen ports evidenced at Macurany represent infrastructural landscape features, which are typically associated with urbanization. The frequency and size of the ports along the lake front at Macurany suggests these were intentionally constructed to provide access to aquatic resources and routes of communication. The spatial patterning of these landscape features also suggests social organization was decentralized at Macurany. The presence of infrastructural landscape features created and managed by a decentralized society challenges Western perceptions of urbanization and infrastructural landscapes where centralization is key. 
Permanent settlement and dense habitation are suggested by the spatial distribution of middens and thickness of terra preta at the site. Middens and terra preta formed at Macurany through intensive deposition, and likely, processes of internal settlement restructuring and reorganization. Although the creation of terra preta was most likely intentional based on the literature regarding the formation of these landscape features (Browne Ribeiro 2017; Kern et al. 2017), the intentionality of the middens at Macurany cannot be confirmed based on surface morphology alone.

The final anthropogenic landscape feature evidenced at and around Macurany are cultural forests. The large concentration of Brazil nut stands and managed palms and fruit trees at the site suggest these forests are not naturally occurring features of the landscape, but were culturally managed and modified by pre-Columbian inhabitants for resource extraction, as seen elsewhere (Lins et al 2015). Although the original distribution of cultural forests at Macurany has changed since pre-Columbian times due to abandonment and contemporary construction and deforestation, local narratives suggest the area was covered in Brazil nut stands. If the distribution of Brazil nut stands was even greater during ancient occupation, this would indicate forest management was a widely practiced subsistence activity that was easily accessed by all inhabitants of Macurany.

Archaeological evidence from Macurany points to a permanent, densely settled, and possibly decentralized society that was actively engaged in modifying the landscape. This analysis contributes towards an understanding of human-environment interaction, landscape formation processes, and urbanization in pre-Columbian Amazonia. 


\section{CHAPTER 2: CULTURAL GEOGRAPHIES OF AMAZONIA}

\section{What is Landscape?}

Landscape archaeology provides a conceptual framework that allows us to examine numerous aspects of past cultures, going beyond interpretation of contexts through a purely environmental perspective. Landscape scientists focus on understanding the interactions between spatial heterogeneity and ecological, geological, and biological processes (Turner 2005), but the focus of this thesis is anthropological so the following framework is adopted. Landscape is not just how culture is mapped onto the environment, but how meaning and culture are created, experienced, and reproduced in space. John Walker defines landscape as the "product of interactions between communities of people and nonhuman entities that is geographically defined and historically specific" (2012: 310). The fact that landscapes are historically and geographically specific makes them potentially contested, given that the same landscape can be experienced differently by different people at different times. However, landscapes also help create and solidify identities and create social boundaries. "Landscape and place are often experienced as a structure of feeling through activities and performances which crystalize and express group identities to the outside world through passing through and identifying with particular places and particular histories" 
(Tilley 2006: 14). In this sense, landscapes are places of memory, experience, and meaning.

Creating landscapes of meaning takes collective work. Tim Ingold (1991) proposed a 'dwelling perspective' to understand how landscapes are created through a pattern of dwelling activities that creates a taskscape. Ingold defined a 'task' as "any practical operation, carried out by a skilled agent in an environment, as part of his or her normal business of life... performed in a series or in parallel and usually by many people working together" (1991: 158). Over time and through repetition, these activities become materialized in the landscape. A taskscape perspective links landscape features to communal actions and groups of people, which provides a basis for understanding local social organization and observing regional variation through spatial analysis.

\section{Landscape Archaeology}

Landscape is a transdisciplinary subject that has been studied in various ways by archaeologists, anthropologists, geographers, geologists, engineers, historians, artists and ecologists. The term landscape has roots in artistic expression. In the $16^{\text {th }}$ century, Dutch painters began depicting rural scenes capturing the subtle changing conditions of everyday life. This technique became known as landscape painting. This definition of landscape evokes a detachment from reality (Strang 2008); something that can be seen and observed, but not felt or experienced. In this sense, the landscape is a backdrop on which human life is lived on, not in. Although the word entered the English language as a Dutch import, it was borrowed from the Germanic root, landschaft, which signified a unit of human occupation (Schama 1995). The duality of landscape as either something to be 
viewed from afar, like a painting, or as a place of dwelling has generated concern among landscape scientists (David and Thomas 2008). In landscape archaeology, a distinction has been drawn between landscape as "a cultural image, a way of representing things" (Daniels and Crosgrove 1988: 11) and landscape as a product of human dwelling (Ingold 1995; Barret 1999; Tilley 2006;). The latter approach, chosen here, permits analysis of human landscape modification and social organization.

The field of landscape archaeology developed in the 1970s, but was more widely practiced in the 1980s. Initially, local ecologies and physical environments were central to landscape archaeology, with research focusing on environmental impacts and limitations on agriculture (Meggers 1971), settlement patterns (Parsons 1972), site distributions in particular environments (Marshall 1978), and artifact distributions (Hirth 1978). Eventually, researchers began to realize that human processes change the landscape, which materially preserves and reflects the history of human engagement with the land (Aston 1997). These processes create what Carl Sauer (1962) called "palimpsests," or the layered records of human activity across space and time. This definition of landscape grew out of Berkeley's Geography Department, and in particular Sauer's geographical research in the Americas, which set the course for those who studied the landscape as a product of human activity that shaped the natural environment. At the same time, the publication of theoretical works on practice by scholars like Bourdieu (1971) and Focault (1970) spurred a growing interest in how social and power relations were materialized in spatial relationships. This shifted the focus of humanenvironmental interaction from purely economical or ecological to socially and culturally embedded. 
A major theoretical shift in landscape archaeology came with the adoption of the perspective of "being-in-the-world" (Merleau-Ponty 1962) by archaeologists, which gave way to the notion that landscape is "an existential ground for our embodied being: we are both in it and of it, we act in relation to it, it acts on us" (Tilley and Cameron-Daum 2017:7). Therefore, bodies and landscapes are products of each other through processes of inhabitation. A more robust understanding of human-environmental interaction emerged, which acknowledged that continual processes of social interaction with a particular landscape can help maintain cultural identity (Strang 2008). It is through the landscape that culture is created, practiced and reproduced. This perspective highlights landscape as the materialization of history and memory (Schama 1995) and as a stage for performance and expression of cultural identity (Keith and Pile 1993; Strang 2001).

The same physical environment can be differentially transformed by diverse cultural groups that create and maintain diverse cultural landscapes (Strang 1997). The way cultural landscapes are formed incorporates every aspect of culture, including cosmology, religion, language, economy, social organization, identity, politics, history and memory, and the material manifestations of those aspects. Landscape archaeology acknowledges landscape as something different from and more than the environment; it is an understanding of being-in-the-world, which involves complex social processes that are not reducible to mere environmental adaptation. Today, landscape archaeologists place people and culture at the core of their analyses with attention to places of meaning (Bender 2002; Tilley and Cameron-Daum 2017:7), spirituality and cosmology (Strang 2008; Schaan 2011), which creates a more nuanced interpretation of how various individual and cultural processes are materially reflected in and shaped by the landscape. 


\section{$\underline{\text { Amazonian Landscapes }}$}

Although South American archaeologists have long had an interest in ancient societies and the landscapes they created, the study of anthropogenic landscapes in Amazonia has been slow to develop. The publication of the Handbook of South American Indians (Steward 1946) crystalized human-environment interaction and landscapes as the primary focus of South American anthropology over the course of the next 70 years. Amazonian landscapes in particular have been viewed from a number of different perspectives, including landscape as an ecological habitat (Steward 1946; Lathrap 1970; Meggers 1971; Erickson 2010; Lombardo and Prümers 2010; Rostain 2013; Kern et al 2017; Watling et al. 2017), in terms of patterns of settlement and subsistence (Lathrap 1977; Roosevelt 1980; Roosevelt 1991; Hecht 2003; Walker 2008; Schaan 2008; OyuelaCaycedo 2008; Heckenberger 2008; Heckenberger et al. 2014; Schmidt et al. 2014; Clement et al. 2015; Carson et al. 2015; Browne Ribeiro 2017; Kern et al. 2017; de Souza 2018; Heckenberger 2018), as built or marked environments (Roosevelt 1999a; Denevan 2001; Erickson and Balée 2006; Heckenberger et al. 2007; Walker 2008; Heckenberger 2008; Clement et al. 2010; Erickson 2010; Lombardo and Prümers 2010; Shepard and Ramirez 2011; Heckenberger 2011; Iriarte et al. 2012; Iriarte et al. 2017; Blatrix et al. 2018;), and as cosmological and performative spaces (Heckenberger 2005; Gaspar et al. 2008; Schaan 2011; Iriarte et al. 2013).

The approach of landscape as an ecological habitat stems from cultural geography (Patterson 2008). This perspective focuses on the interaction of communities and their physical environment, and more specifically for Amazonian archaeology, how or whether environments limit development in society. In Amazonia, early anthropologists (Steward 
1946; Lathrap 1970; Meggers 1971) saw the ecological landscape as something that determined the ways in which culture developed or adapted. Lowie (1948) defined the entire Amazon region as the Tropical Forest area. Within this Tropical Forest area, Lowie (1948) defined the Tropical Forest Complex (TFC), which he distinguished from Andean civilizations that had monumental architecture and metal tools, and other so called "marginal" cultures within the Tropical Forest area that practiced a hunting-gathering economy. The main diagnostic features of the TFC included the cultivation of root crops and the manufacture of pottery. According to Lathrap (1970) and Meggers (1971), the TFC had the most potential to develop on the fertile floodplains (várzea) along major whitewater rivers where intensive agriculture was possible, leaving the majority of Amazonia, the uplands (terra firme), with little potential for TFC development. However, the division of such a vast landscape into two narrowly defined ecological zones masks the heterogeneity of Amazonian environments and cultures and has implications on the credibility of early anthropological models. In recent years, Amazonian archaeologists have demonstrated how dramatically ancient cultures transformed and modified their surrounding ecological habitats and built the landscapes in which they lived (Erickson 2010; Lombardo and Prümers 2010; Rostain 2013; Kern et al 2017; Watling et al. 2017). A new perspective of landscape as an ecological habitat has emerged, which continues to focus on human-environment interaction, but acknowledges individual and community agency in landscape change and modification. The research presented here adopts a historical ecology framework to understand landscape formation and modification at Macurany. 
Amazonian landscapes have also been defined in terms of settlement and subsistence patterns. This definition of landscape recognizes that human subsistence and settlement activities leave patterned features across the landscape that can be linked with individual communities. This allows archaeologists to understand of human-environment interaction within a particular settlement or across a region. Amazonian archaeologists studying settlement patterns have primarily been concerned with understanding spatial relationships between settlement systems and subsistence activities (Lathrap 1977; Roosevelt 1980), social hierarchies expressed in settlement patterns (Roosevelt 1991; Schaan 2008), and the relationships among communities residing in different regions (Heckenberger et al. 2014; de Souza 2018). Studying settlement patterns has proved useful for understanding social organization and the interconnectedness of community members, villages, cities, and regions in ancient Amazonia.

Combining the study of settlement and subsistence patterns pushes archaeological investigation beyond site hierarchies and regional settlement patterns providing a more nuanced understanding of community organization, resource management, and landscape modification. Subsistence systems concern the relationship among communities, subsistence activities and the environment. This perspective does not see the landscape exclusively in terms of settlement (Patterson 2008), but instead incorporates the larger surrounding utilized landscape and environmental setting in which the community is situated. This is especially important for understanding Amazonian landscapes, where subsistence systems are much more complex due to the abundance of microhabitats spread across the landscape. Studying settlement patterns and subsistence systems in combination illuminates aspects about politics and trade (Heckenberger et al. 2017) and 
provides a clearer understanding of ancient resource management (Schaan 2008; OyuelaCaycedo 2008; Carson et al. 2015), landscape formation processes (Hecht 2003; Schmidt et al. 2014; Browne Ribeiro 2017; Kern et al. 2017), and social organization at local and regional scales in Amazonia (Walker 2008; Heckenberger 2008; Clement et al. 2015; Heckenberger 2018).

Although the perspectives of landscape as ecological habitat and patterns of settlement and subsistence acknowledge human agency in landscape formation processes, they do not explicitly acknowledge human intent. The perspective of landscape as a built or marked environment emphasizes the relationship between intentionally built landscapes and how those constructions affect or make society. Built environments require investments of labor, while marked environments require not only investments of labor, but also investment of meaning (Walker 2012). Built and marked environments include agricultural infrastructure (Erikson 1995; Oyuela-Caycado 2008), such as raised fields and canals (Erickson and Balée 2006; Walker 2008; Rostain 2012; Carson et al. 2015; Clement et al. 2015;), as well as landscape features unrelated to production or agriculture, such as rock art or geoglyphs (Roosevelt et al. 1996; Mayle and Iriarte 2014; Cavallini et al. 2015). Landscapes can also be marked even in the absence of physical markers, as in landscapes of movement, which are repositories of meaning, memory, and history (Snead et al. 2009). In Amazonian archaeology, built and marked environments have been studied to understand early human occupation in Amazonia (Roosevelt 1999a), agriculture and domestication (Denevan 2001; Clement et al. 2010; Iriarte et al. 2012, Blatrix et al. 2018; ) implications on biodiversity (Erickson and Balée 2006; Heckenberger et al. 2007; Shepard and Ramirez 2011), language dispersals (Walker 
2008; Heckenberger 2011), spheres of interaction (Iriarte et al. 2017) and social complexity and urbanization (Heckenberger 2008, Erickson 2010; Lombardo and Prümers 2010).

The perspective of landscape as cosmological and performative space is the most recent development in landscape studies in Amazonia. This perspective seeks to understand the link between the terrestrial world and the symbolic world, which requires cross-disciplinary conversations between archaeologists, ethnologists, linguists, historians, mythologists and performers. In Amazonia, archaeologists have focused on how the landscape functions as a stage for public and ritual performance (Heckenberger 2005), the reproduction of cultural norms and social relations (Gaspar et al. 2008; Iriarte et al. 2013), and the transformation of the ordinary into the unordinary (Schaan 2011).

These four main perspectives of landscape have influenced how ancient humanenvironment interaction in Amazonia has been studied and understood over the past 70 years. Archaeologists acknowledge that pre-Columbian Amazonians contributed to the formation of the landscape and that the history of human engagement with the land is materially preserved and reflected in the form of landscape features.

\section{Landscape Features}

Large Amazonian settlements along the main river channels were recorded by early European explorers (Carvajal [1934] 1970), but attention to ancient settlements and associated landscape features in Amazonia was largely ignored until the 1950s (Meggers 1954; Meggers and Evans 1957), with exceptions (Hartt 1874; Katzer 1903; Nimuendajú 1924), and did not garner much attention until the 1980s (Roosevelt 1980; Smith 1980). 
Amazonian landscape features include raised fields, trails, roads, causeways, canals, ports, fishing and turtle weirs, man-made ponds, middens, terra preta, terra mulata, ringed ditches, geoglyphs, platforms, plazas, terraces, palisades, habitation mounds, ceremonial mounds, funerary mounds, forest islands, megaliths and managed forests. Amazonian archaeologists tend to group landscape features according to function or specific tasks associated with those features. Five primary functions of pre-Columbian earthworks have been identified: settlement, subsistence, defense, cosmological, and infrastructure (Schaan 2011; Rostain 2013). However, an important category has received little attention: infrastructure. Infrastructural landscapes emerge through interactions, planning, and collective investments of labor among communities, which requires social organization, political connections, and collaboration, and provide the basic necessities for large scale populations, regional polities, and urbanization. Large, socially complex communities with long distance communication and trade networks require infrastructure to manage cultural, political, religious, and economical flow between centralized regions and peripheral areas. Unlike other landscape features, infrastructural landscape features are built to last for generations and represent an investment in permanence. Infrastructural landscape features include waste management systems, such as sewers and drains, subsistence structures, such as reservoirs, irrigation canals, and terraces, and communication networks, such as highways, roads, and trails, to name a few. Infrastructural landscapes are hardly mentioned in discussions revolving around Amazonian landscapes and are reported almost exclusively in terms of subsistence and agricultural production (Oyuela-Caycedo 2008; Erickson 2010; Arroyo-Kalin 2010; Walker 2011; Lombardo and Prümers 2012; Carson et. al 2015). This is probably due to 
the fact that debates about Amazonian cultures have been focused on agriculture and not on urbanization.

Walker (2011) also proposed a method for categorizing Amazonian landscape features based on task, rather than function. Walker (2011: 287) recognized six main categories of landscape features based on tasks that are associated with those particular features, including farming, construction and maintenance, hunting and fishing, water management, fire management, and transportation. These tasks can help identify and understand the function of a particular landscape feature. Although I identify five primary functions of Amazonian landscapes, it is important to note that the original intended purpose of a landscape feature can shift and multiply over time.

Subsistence landscape features in Amazonia include raised fields, canals, fishing and turtle weirs, ponds, managed forests, shell middens, and forest islands. Raised fields were used for agriculture and have been evidenced in the Llanos de Mojos (Erickson 1995; Erickson and Balée 2006; Walker 2008; Mayle and Iriarte 2014; Carson et al. 2015), the Orinoco (Clement et al. 2015), Amapa (Clement et al. 2015), Para (Clement et al. 2010), the French Guianas (Iriarte et al. 2012; Rostain 2012), and Suriname (Versteeg 2008). Raised fields are commonly associated with canals, which irrigate raised agricultural fields and provide routes of transportation during the rainy season, and causeways that connect agricultural fields to residential areas.

Fishing and turtle weirs and man-made ponds were used for aquaculture and food storage. Blatrix et al. (2018) have recently documented fishing weirs and ponds in the Llanos de Mojos, but they have also been found in other regions of Amazonia, including the Central Amazon (Schmidt et al. 2014), the Belterra Plateau (Clement et al. 2015), 
Marajo Island (Schaan 2008) and French Guiana (Rostain 2012). Turtle weirs have been evidenced in the Central Amazon at the Hatahara site (Prestes-Carneiro et al. 2016). These features are also commonly associated with canals, which connect ponds and fishing weirs to main water sources so fish can enter during periods of flooding and become trapped when water levels recede. Canals are not only useful for water and fishery management, but also serve as routes of transportation during the rainy season.

Evidence of forest management exists in numerous places around Amazonia, which suggests it was a widely practiced subsistence activity. Anthropogenic forests, Brazil nut stands and managed palms in particular, have been documented all across Amazonia (Denevan 2001; Clement et al. 2010; Shepard 2011; Erickson 2010; Balée 2013; Watling et al. 2017). Brazil nut stands have been found in association with terra preta (Balée 1989; Conklin 2001; Neves 2016) and geoglyphs (Shepard 2011). The distribution of Brazil nut trees is most likely anthropogenic because humans and a small rodent, the agouti, are the only animals able to penetrate the hard Brazil nut pods to access the fruit and the seeds are heavy and do not float so natural distribution across bodies of water is unlikely. Brazil nut trees grow in dense stands of up to 100 individuals per stand, which is uncommon in most similar species, and can grow up to 50 meters in height and live up to 500 years (Neves 2016). Mature trees can produce around 300 pods during peak season with each pod producing on average 25 seeds (Neves 2016). Brazil nut trees require ample sunlight, which also suggests ancient Amazonians were clearing places for Brazil nut trees to grow and managing existing stands.

Other economically useful tree species that have been associated with preColumbian forest management include hog plum (Spondias mombin), kapok (Ceiba 
pentandra), ochoo (Hura crepitans), genipapo (Genipa Americana), bamboo

(Bambusoideae), pequi (Caryocar brasiliense), acaucaria (Araucaria araucana), and various species of palm (Balée 1993; Erickson and Balée 2006; Neves 2016; Watling et al. 2017). This evidence suggests that managed forests were an integral part of ancient Amazonian subsistence systems.

Shell middens are associated with subsistence, attesting to shellfish consumption, and result from the high accumulation of shells in specific areas. Shell middens have also been associated with settlement (Roosevelt et al. 1991; Lombardo et al. 2013; Pugliese et al. 2018) funerary activities (Gaspar et al. 2008; Pugliese et al. 2018), and hydraulic control and management (Schaan 2008). Shell middens are primarily found at the mouth of the Amazon River at Marajo Island (Schaan 2008) and East Coastal areas (Pugliese et al. 2018), but have also been observed along the Lower Amazon River at the Taperinha site (Schaan 2011) and other sites along the Lower Xingu (Pugliese et al. 2018), and the Monte Castelo site in the Llanos de Mojos (Lombardo et al. 2013). Recent research on shell middens in these regions show that these landscape features were first earthen mounds upon which shell middens accumulated. The switch from earth to shell mounding marks a change in function and co-occurs with the appearance of new plants and the development of sophisticated technology, such as ceramics (Roosevelt et al. 1991; Pugliese et al. 2018). In certain areas, such as the wetland areas of the Llanos de Mojos, biodiversity rich refugia or forest islands formed on shell middens during periods of inundation and became important features of the landscape for humans, animals, and plants alike (Balée 2010; Lombardo et al. 2013). 
Landscape features associated with settlement in Amazonia include terra preta, habitation mounds, plazas, terraces, middens, and geoglyphs. Terra preta is an anthropogenic soil formed through in-situ processes and is composed of high levels of soil organic matter, biochar and ceramics. Three edited volumes describe these soils (Glaser and Woods 2004; Lehmann et al. 2003; Woods et al. 2009), which stretch for kilometers along the main rivers and tributaries, as well as in some interfluvial areas. Terras pretas are clearly artificial and associated with ancient settlement and habitation (Hecht 2003; Browne Ribeiro 2011; Schmidt et al. 2014; Arroyo-Kalin 2014; Browne Ribeiro 2017; Kern et al. 2017). In areas along the main channels of the Amazon River, terra preta has been associated with large, permanent settlements (McEwan et al. 2001; Arroyo-Kalin 2014). A distinction has been made between terra preta, which is associated with ancient settlement and habitation, and terra mulata, which is thought to be associated with ancient subsistence practices (Browne Riberio 2017; Kern et al. 2017; Isendahl et al. 2019). Terra mulata is characterized by lighter colored soil and little to no ceramics.

Habitation mounds, including platforms and monumental settlement mounds, are found in various regions around the Amazon. The most documented region is the Llanos de Mojos (Erickson and Balee 2006; Lombardo and Prumers 2010; Walker 2011; Schaan 2011; Mayle and Iriarte 2014; Carson et al. 2015; de Souza 2018). Other regions in Amazonia where habitation mounds have been recorded include the Upano Valley (Rostain 2012), the Colombian Amazon (Oyuela-Caycedo 2008), Suriname (Versteeg 2008) Marajo (Schaan 2008), the Central Amazon (Browne Ribeiro 2017; Moraes and Neves 2019), and the Lower Amazon around Santarém (Heckenberger 2008; Schaan 2011). 
Middens have also been associated with settlement in Amazonia. Middens are areas of refuse that build up around habitation areas, typically forming circular or ringed mounds. Circular middens have been evidenced in Marajo and the surrounding area (Schaan 2011). Ring-shaped middens have been recorded in the Xingu (Heckenberger 2008; Schmidt et al. 2014), at the mouth of the Amazon River (Browne Ribeiro et al. 2016), the Lower Amazon river (Lima et al. 2002; Heckenberger 2008), the Trombetas River (Schmidt et al. 2014) and in the Central Amazon (Mayle and Iriarte 2014; Schmidt et al. 2014; Browne Ribeiro 2017; Kern et al. 2017).

Habitation mounds and middens are commonly associated with roads, terraces and plazas where people, goods, and services were moved and traded and social functions took place. Heckenberger (2008) has documented numerous plaza communities in the Xingu that are connected by roads forming galactic clusters. Other areas where plazas have been recorded include the Central Amazon (Wust and Barreto 1999; Schmidt et al. 2014; Browne Ribeiro 2014), the Colombian Amazon (Oyuela-Caycedo 2008), and the Upano River valley (Rostain 2012). Terraces have been observed in association with middens and habitation mounds, but middens are more widely reported with terraces. Terraces are typically flat areas where houses were constructed. Terraces have been recorded in the Ecuadorian Amazon (Rostain 2012), the Colombian Amazon (OyuelaCaycedo 2008), the Central and Lower Amazon (Schmidt et al. 2014) and at the mouth of the Xingu River (Browne Ribeiro et al. 2016).

Geoglyphs are the final Amazonian landscape feature associated with settlement. Geoglyphs are found exclusively in the south western region of Amazonia (Mayle and Iriarte 2014; Watling et al. 2017; de Souza et al. 2018). Although their exact function has 
not been determined, geoglyphs are commonly found in or near ancient Amazonian settlements. Clark Erickson (2010) has proposed multiple functions for geoglyphs, including defense, settlement, residences for the elite, resource markers, traps for animals, water management features and ceremonial centers. Geoglyphs range in size, but are generally either circular, square, or hexagonal. Although circular geoglyphs are structured similarly to ringed ditches, they are more precise in their geometry.

Defensive landscape features are found across Amazonia and include palisades and ringed ditches. Ringed ditches are most likely the archaeological evidence of palisaded villages (de Souza 2018). Fortified villages associated with ringed-ditches and palisades have been observed in the Central Amazon (Neves and Tamanaha 2012), the Lower Madeira River (Moraes and Neves 2019), the Llanos do Mojos (Walker 2008; Erickson 2010; Carson et al. 2015; Erickson 2010; Blatrix et al. 2018), the Xingu (Heckenberger 2008; Schmidt et al. 2014) and Suriname (Versteeg 2008).

Amazonian landscape features associated with cosmology are often sacred in function and are used in rituals, ceremonies and mortuary rites, though they may also have mundane functions. Cosmological landscapes include funerary and ceremonial mounds, geoglyphs, and megalithic monuments. Funerary and ceremonial mounds have been evidenced in the Colombian Amazon (Oyuela-Caycedo 2008), the Central Amazon (Machado 2005; Rapp Py-Daniel 2009; Schaan 2011), the southern Brazilian Highlands (Iriarte et al. 2013), and Marajo (Schaan 2011). These mounds are associated with human burials and artifacts that indicate ceremonial function and are usually found in and around settlements. 
As mentioned earlier, geoglyphs have been attributed numerous functions. However, some scholars have suggested that geoglyphs were ceremonial centers (Erickson 2010; Watling 2017; de Souza 2018). Evidence of ceremonial function is based on the lack of cultural material found within the enclosed area of the geoglyphs and the regularized form of the geoglyphs. Both lines of evidence point to a "clean," possibly ceremonial space within the geometric earthworks.

Megalithic monuments have only been reported in one area of Amazonia in the north eastern state of Amapá (Mayle and Iriarte 2014). These megalithic monuments have been observed at over 30 sites and are usually found encircling chambered tombs containing funerary urns (Cabral and Saldanha 2008). These megaliths definitively mark sacred landscapes.

The final category of landscape features in Amazonia is infrastructure. Amazonian landscape features associated with infrastructure include trails, roads, causeways, canals, ports, and any other feature that is considered vital to the daily operations of a particular society. Trails and roads are found throughout Amazonia and provide the basic infrastructure that connects towns, villages, cities, and even entire regions. Causeways are raised roads that are evidenced in numerous parts of Amazonia, including the Llanos de Mojos (Erickson 1995; Walker 2008; Mayle and Iriarte 2014; Carson et al. 2015; Clement et al. 2015; Blatrix et al. 2018), the Xingu (Walker 2011; Schmidt et al. 2014; Clement et al. 2015) the Orinoco (Clement et al. 2015), the Guianas (Rostain 2012; Clement et al. 2015) and the Central Amazon (Clement et al. 2015).

Canals were used for both water management and transportation. Canals have been reported in the Llanos de Mojos (Erikson 1995; Erickson and Balee 2006; Walker 
2008; Clement et al. 2015), the Xingu (Clement et al. 2015), the Central Amazon (Schmidt et al., 2014), the Middle Amazon River (Clement et al. 2015), the Belterra Plateau (Clement et al. 2015), and Marajo Island (Clement et al. 2015).

Although ports must have been crucial to trade, communication, and social and political networks in riverine environments, they have not been extensively reported in Amazonia. Archaeological data on ports in Amazonia is scant. Schmidt et al. (2014) have reported large linear depressions leading from the bluff edge down to ports/bathing areas along the waterfront at sites along the Solimões River and the Central Amazon, but provide no systematic description of the ports. Browne Riberio et al. (2016) have also documented riverine access routes on the Lower Xingu. Ethnographic evidence of Amazonian ports was reported by William Lipkind (1948), who recorded port use among Carajá populations on the inland island of Bananal, which is located in the Southeast region of the Amazon. Lipkind (1948) describes Carajá settlements as having two ports; a main port, which is the center for bathing and landing canoes, and a bachelors' port, which is connected by a path to the men's house and is used by young men and visitors. Although Lipkind's (1948) description of Carajá ports is useful, it is important to proceed with caution when comparing ethnographic evidence with archaeological data. Ports must have existed in an environment where aquatic resources were crucial for subsistence, trade, and communication. However, more archaeological data is needed to make any further conclusions about port infrastructure in Amazonia.

\section{Ports and Anthropogenic Landscapes}

Amazonian landscapes are the material records of human engagement with the land and provide archaeologists unique glimpses into the past that allows us to gain a 
fuller understanding of ancient landscape use, modification and spatial social organization. The variety, frequency and distribution of ancient landscape features across Amazonia represents a complex and diverse cultural landscape that existed in preColumbian times. Landscapes of subsistence, settlement, defense, cosmology, and infrastructure are all preserved in the archaeological record and can help piece together the complex histories of pre-Columbian Amazonians.

Studying ancient anthropogenic ports is crucial for understanding the social structure and organization of riverine societies whose livelihoods, trade and communication networks, and political systems would have depended on aquatic resources. Amazonian ports have garnered little attention, likely due to that fact that the material evidence for ports in the Amazon does not match the Western perception of form and material components. Additionally, ports may be associated with the class of complex societies from which Amazonian cultures have historically been excluded. Studying ports within an anthropological archaeology has the potential of furnishing a more nuanced understanding of settlement, trade, subsistence, and the integration of places in landscapes dissected by water. Ports are also zones where social interaction among community members, and also between insiders and outsiders takes place, which means dimensions, such as social and economic organization, can be gleaned from studying ports.

The anthropogenic ports evidenced at Macurany demonstrate inhabitants were intentionally modifying their surrounding landscape constructing ports at regular intervals along the lakefront, which provided access to aquatic resources and opened up routes of communication and trade. The size and frequency of the ports at Macurany 
suggests social organization was non-hierarchical and spatially decentralized. The presence of infrastructural landscape features, such as ports, also indicates technological ingenuity and collaboration. Their frequency may point to emerging urbanization. The archaeological evidence at Macurany represents a decentralized community practicing intensive landscape engineering, which challenges traditional perceptions of infrastructural landscapes and urbanization, in which centralization is key. 


\section{CHAPTER 3: REGIONAL BACKGROUND}

\section{Early Landscape Modification}

Humans are believed to have arrived in Amazonia around 16,000 BP (Schaan 2011). Shortly after their arrival, paleoindians began managing the forest and marking the landscape with rock art. Some of the earliest evidence of anthropogenic landscape modification in Amazonia comes from Caverna da Pedra Pintada (Roosevelt et al. 1996), which is situated on the north side of the Lower Amazon River across from Taperinha in Monte Alegre. Stylized rock paintings date roughly to 11,000 BP and include red and yellow geometric motifs, anthropomorphic figures, animals, and adult and children handprints. Archaeobotanical remains, such as Brazil nut (Bertholetia excelsia), Jutaí (Hymenaea cf. parvifolia and oblongifolia), achuá (Sacoglottis guianensis), pitomba (Talisia esculenta), muruci da mata (Byrsonima crispa), apiranga (Mouriri apiranga), tarumã (Vitex cf. cymosa), sacurí, (Attalea microcarpa), tucumã (Astrocaryum vulgare), and curuá (Attalea spectabilis) were also recovered from the site suggesting inhabitants were highly adapted to humid tropical forest environments and subsisted heavily on forest and floodplain resources (Roosevelt et al. 1996). Many of the tree species harvested by paleoindians at Caverna da Pedra Pintada are still found and managed in the tropical forests of Monte Alegre, which has led some scholars to believe paleoindians were altering and managing the forest (Roosevelt et al. 1996; Oliver 2008; Neves and 
Petersen 2008; Schaan 2011). The evidence from sites like Caverna da Pedra Pintada demonstrates paleoindians were utilizing a broad range of forests resources and possibly modifying landscapes during the late Pleistocene in Amazonia.

By the early to mid-Holocene, fishing villages were established along major waterways. The earliest evidence of these fishing villages comes from the Taperinha shell mound located near the mouth of the Tapajos River, which dates to around 7,000 BP (Roosevelt et al. 1991; Roosevelt 2000; Schaan 2011). Shell middens have also been found elsewhere in Amazonia, including the Lower Xingu River (Pugliese et al. 2018), Marajó Island (Schaan 2008), and the north Atlantic shore (Pugliese et al. 2018), but date to around 5,500 $\mathrm{BP}$ to 4,000 $\mathrm{BP}$. This time period is also associated with an increase in palm species around archaeological sites, which suggests an increased focus on palm management among pre-Columbian Amazonians (Neves and Petersen 2008).

A radical shift in social and economic organization occurred in Amazonia around 2,500 BP (Neves and Petersen 2008). An increase in settled, permanent villages begin to appear along the bluffs of lake shores and smaller tributaries (Schaan 2012; Levis et al. 2014). The most visible forms of landscape modification from this time period include terras pretas, raised fields, artificial mounds, burial mounds, plazas, defensive ditches, roads, causeways, and irrigation and transportation canals. These forms of intensive landscape modification persisted in Amazonia until European contact.

\section{$\underline{\text { Regional History }}$}

The region surrounding Macurany stretches from the confluence of the Rio Negro and Solimões River around the modern day city of Manaus in the Central Amazon to the 
city of Santarém and the surrounding vicinity on the Lower Amazon River encompassing both the north and south side of the Amazon River (Figure 1). Macurany is located along the course of the Middle Amazon River in Parintins. The region is characterized by lowland tropical forests, high temperatures, rainfall and humidity, and poor, leached, and acidic soils. Nutrient rich white water rivers dominate the region, with nutrient poor black water rivers, such as the Rio Negro, contributing to the hydrology in the Central Amazon, and clear water rivers, like the Tapajos, appearing in the Lower Amazon. River channel meandering and seasonal flooding continually modify the landscape, forming

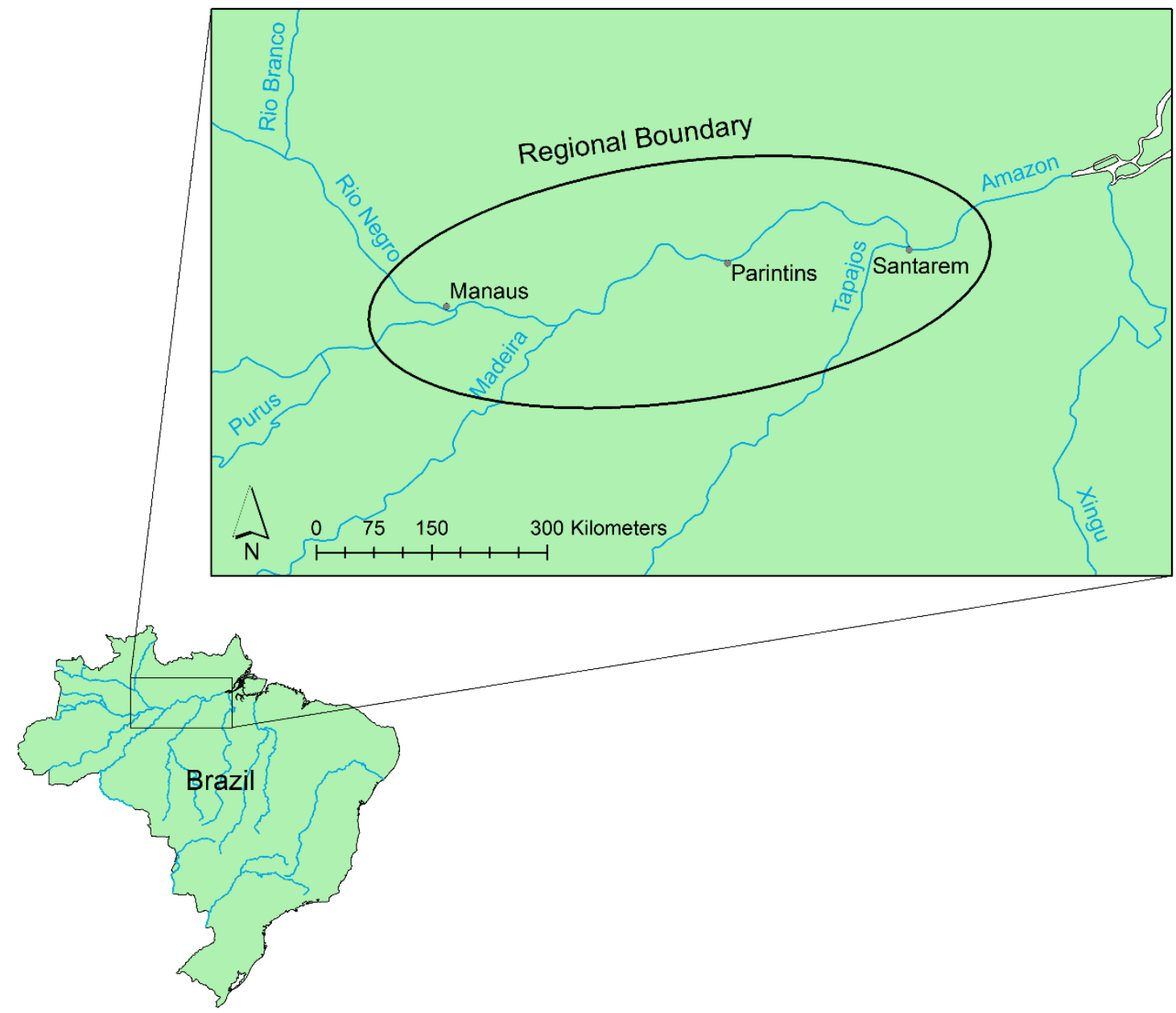

Figure 1. Region surrounding Macurany. 
natural levees, islands, and lakes, and creating habitats for floating forests and grasslands. In the Central Amazon, the river is wider and floodplains extend for greater distances, providing more nutrient-rich soils for agricultural production. In contrast, in the Lower Amazon the river channel narrows and the size of the floodplains decreases. The highly fluctuating environment of the floodplain results in the formation of microhabitats with greater biotic diversity (Moran 1993). The ecological diversity in this region made it highly attractive to early inhabitants (Moran 1993; Neves 2008).

The floodplain was of particular importance to early Amazonian archaeologists (Lathrap 1970; Meggers 1970), who believed permanent agricultural societies were most likely to development in the várzea. However, it is unlikely that intensive settlements were established on the active floodplains (Lima et al. 2002). Additionally, the presence of terra preta and other anthropogenic features on bluffs overlooking floodplains and lakes suggests ancient Amazonians were not actually living on the floodplains, but occupied the terra firme areas where the environment was more stable.

The great morphological dynamism of the floodplains required intensive landscape engineering and management. Although anthropogenic landscape modification has been evidenced at numerous archaeological sites along the Amazon River, there is great variation in the type and spatial distribution of landscape features between the Central and Lower Amazon. This could possibly be due to environmental factors. Rainfall and flooding are more consistent throughout the year in the Central Amazon than the Lower Amazon, which experiences greater inundation during the wet season. This could lead to different types and patterns of landscape engineering in the Lower and 
Central Amazon. However, cultural factors also influenced how and where landscapes were modified.

Intensive landscape modification in the Central Amazon can be traced back to around 2,000 BP (Neves and Petersen 2008; Schaan 2011; Browne Ribeiro 2014; Arroyo-Kalin 2014). Landscape features in the Central Amazon include terra preta, terra mulata, plazas, habitation and funerary mounds, defensive structures and ditches, agricultural areas, and wetland and forest management systems. Terra preta is the most common marker of archaeological sites in the Central Amazon. Terra preta sites in this region are frequently found on bluffs along major tributary rivers and lakes (Schaan 2011; Levis et al. 2014). This engineered soil was created through long term occupation and internal restructuring of habitation sites and intentional charring of refuse in middens (Schmidt et al. 2014; Browne Ribeiro 2017; Arroyo-Kalin 2017; Kern et al. 2017). These middens sometimes form around domestic spaces in a ringed, linear, or honey-combed pattern forming a middenscape (Browne Ribeiro 2011; Schmidt et al. 2014). Middenscapes have also been found along the Trombetas River, the Uruburu River and the lower Xingu River (Lima et al. 2006; Browne Ribeiro et al. 2016; Kern et al. 2017).

Common settlement patterns in the Central Amazon are ringed and linear villages, which appear with the emergence of regional polities around 1,300 BP. These settlements are composed of habitation mounds or structures arranged in a circular or linear pattern typically surrounding a central plaza (Wust and Barreto 1999; Moraes 2007; Browne Ribeiro 2014; Neves 2013). In some cases, ringed and linear villages are enclosed by defensive ditches (Neves and Petersen 2008; Schaan 2011; Schmidt et al. 2014). 
The settlement pattern in the Central Amazon reflects a dispersed regional landscape where people are living in smaller settlements that are linked with larger residential and ceremonial centers (Heckenberger et al. 2007; Neves 2013). There is no clear evidence of centralized authority or institutionalized social inequality. Some scholars have attributed this to the abundance and predictability of resources in the Central Amazon region (Neves 2013).

The Lower Amazon exhibits some similarities in patterns of settlement and landscape modification as the Central Amazon. Landscape features include habitation mounds, ritual caches, trail networks, terra preta, terra mulata, and managed forests and wetlands (Roosevelt 1999b; Gomes 2001; Heckenberger 2008; Schaan 2012; Levis et al. 2014). Similar to archaeological sites in the Central Amazon, Lower Amazonian sites are also commonly situated on bluffs along lake shores and tributary rivers and feature anthropogenic soils. However, the formation of terra preta in the Lower Amazon does not conform to the middenscapes model. The presence of large gardens composed of terra mulata in the Lower Amazon suggests these soils were intentionally prepared by humans for cultivation (Schaan 2011; Neves 2013).

The Lower Amazon was regionally organized from around 1,500 BP onwards (Schaan 2011). Settlement patterns in the Lower Amazon reveal a highly stratified society and large tributary polity (Heckenberger et al. 2007; Heckenberger 2008; Schaan 2011). At Santarém, Roosevelt (1999b) concluded the site was of urban scale and complexity based on the arrangement of long houses, low mounds, caches of fine pottery and vessels, and large terra preta middens. Smaller settlements along tributary rivers, 
lakes, and interfluves are also present in the area and most likely served as nodes in regional trade networks (Schaan 2011).

Although inhabitants of both the Lower and Central Amazon occupied similar ecological environments and actively managed the landscape, the archaeological evidence shows two different regional polities existed in the area surrounding Macurany. The ringed villages and middenscapes in the Central Amazon demonstrate preColumbians were intensively modifying the landscape and maintaining permanent, densely populated settlements, however, there was no institutionalized political centralization. In contrast, landscape modification and settlement organization in the Lower Amazon reflect a highly stratified, centralized, tributary society. These regional differences seen in landscape modification and settlement patterns, as well as other factors, contextualize the region surrounding Macurany. These differently organized societies nonetheless shared technological innovations, such as terra preta, and possibly trade networks, material goods, people, and ideas. This region along the Middle Amazon River, where Macurany is situated, could be key to understanding the relationships and possible boundaries that existed between these two regional polities.

\section{Macurany}

Macurany is located on Tupinambarana island in the Middle Amazon River in Parintins (Figure 2). Parintins is located on the far eastern edge of Tupinambarana at an intersection between the Amazon River and smaller river channels and inland lakes. Macurany is situated on a bluff along the shores of Lake Parananema, an oxbow lake located just south of Parintins. The site is located between the northwestern lakeshore and a modern road that connects the recently constructed Vila Cristina neighborhood to the 


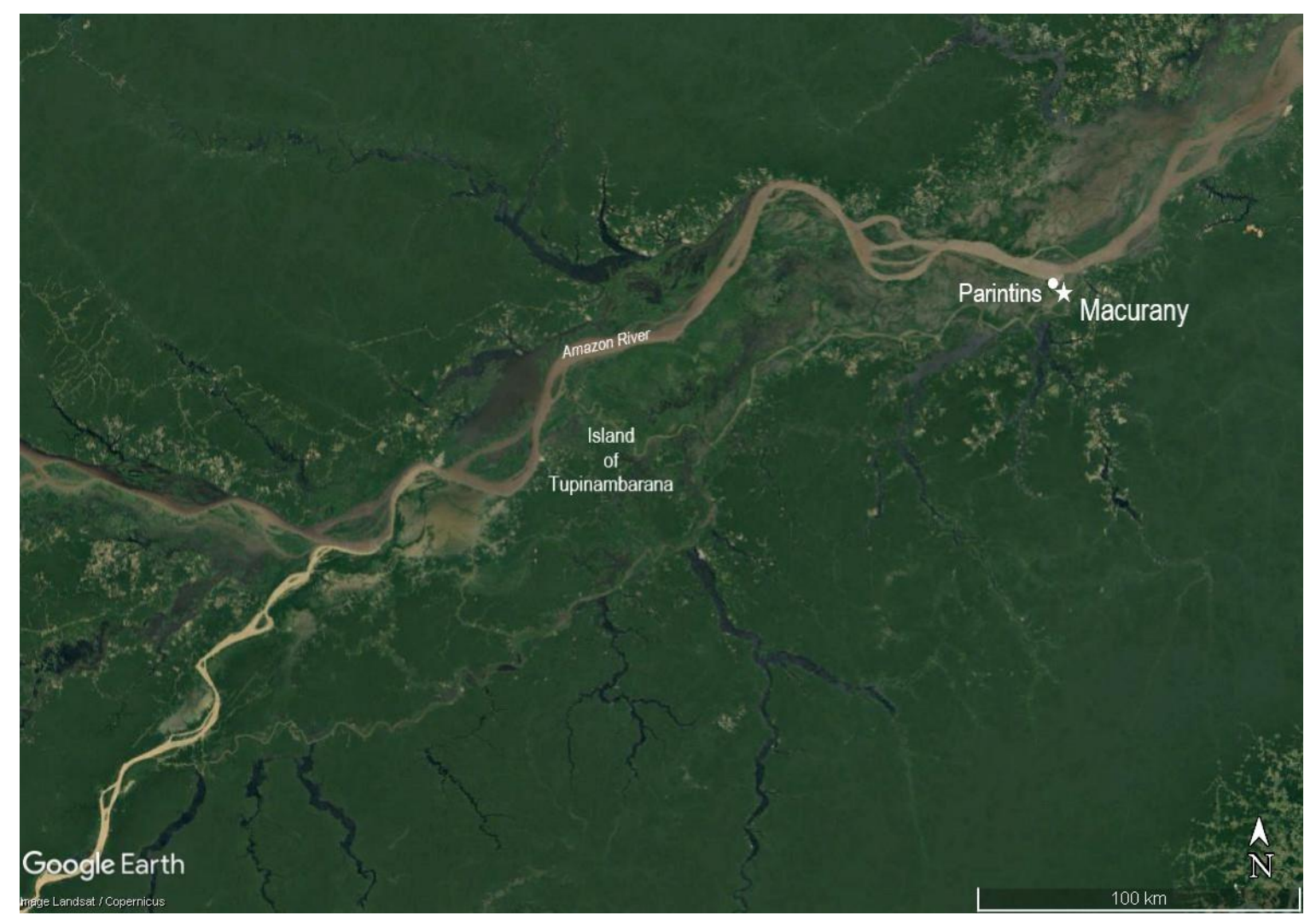

Figure 2. Location of Macurany.

city of Parintins. The habitation zone extends approximately 200 meters inland from the shores of Lake Parananema. The southwestern and northeastern extents of the site were not mapped because the site is located on privately owned property, and access was limited to the portion visible in Figure 3. Brazil nut stands (Bertholetia excelsia) and inajá palms (Attalea maripa) enclose the site to the northwest and northeast, leaving a small portion of the lakefront and the southwestern side mostly clear of vegetation.

Anthropogenic ports were identified at regular intervals along the lakeshore. Of the eighteen ports reported by Macurany community members, nine were verified by members of the Tupinambarana Project, one of which has been destroyed by recent construction, but can still be detected. Terra preta extends from the lakefront and 
decreases as it approaches Vila Cristina. Elevated areas of terra preta are found a few meters inland from the ports.

Rural smallholders own and maintain the property where the site is located. There are four modern structures located on the site used for housing and work. The ports are used frequently by site inhabitants for swimming, playing and docking their boats. Gardens are maintained on the land between the ports. Portions of the continuous extent of terra preta are used for cultivating manioc. A variety of mixed managed forests are maintained closer to the homes, while Brazil nut stands (Bertholetia excelsia) are managed farther from domestic areas. Current site inhabitants regularly harvest Brazil nuts for consumption and use the empty shells as fuel for kitchen fires. 


\section{CHAPTER 4: SURVEY OF MACURANY}

The Tupinambarana Project is an international collaboration between the University of Louisville (UL), the Universidade do Estado do Amazonas (UEA), the Museu da Amazonia (MUSA), and community members from Parintins, and co-directed by Dr. Filippo Stampanoni of the MUSA and Dr. Anna Browne Ribeiro from UL. The project was initiated by local Parintins community members and professors from UEA, including Dr. Clarice. Community outreach, input and support were significant to the methodology and objectives of archaeological research at Macurany. Local community members drove initial research goals and provided unique insights and observations about the history and recent use of the site. Students, professors and community members involved with the Tupinambarana Project were crucial to the project's outcomes and success, without which we would not have had the opportunity, logistical support, or tools to map, survey, and document the site.

Survey took place over the course of ten days during July 2017. Members of the rural smallholder family were engaged with the survey and provided crucial information about recent site use. The extent of the survey was determined based on access, which was negotiated with the owners of a specific piece of property, as well as by time and research priorities. The survey was contained within the boundaries of the private territory (Figure 3) and covered approximately 110,600 $\mathrm{m}^{2}$ extending from the lakeshore 
to the road side and included

open air areas along with areas

of dense vegetation. Data

collection was prioritized around

mapping the topography of

anthropogenic features located

in highly visible, open air

portions of the site. Densely

vegetated areas of the site were

also surveyed, but not mapped

as extensively as open air areas.

\section{A northwest transect}

from the lakeshore to the

roadside helped determine two

of the site boundaries. A more

detailed survey was conducted

in the zone near the lakeshore,

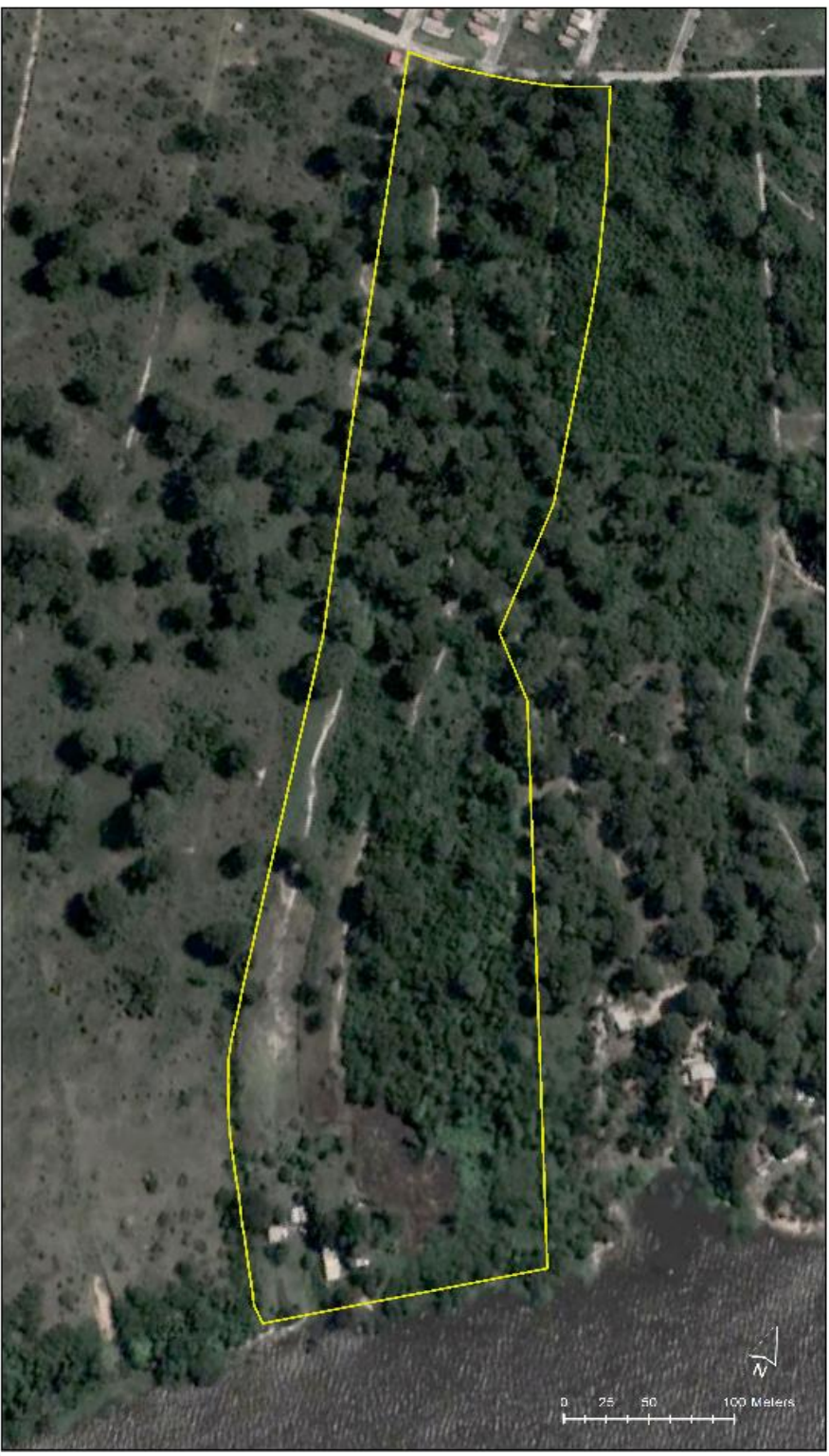

Figure 3. Extent of surveyed area at Macurany.

an open-air, clear-cut portion of the site with high visibility of the ground surface, which

was important for topographic mapping purposes. Three ports were selected for mapping because of accessibility and visibility. Although fifteen other ports were reported in the area, they were excluded from the survey due to dense vegetation, limited visibility and access, and time constraints. Survey included mapping site topography and modern features. 


\section{Mapping}

Site topography and modern features were mapped using a Sokkia CX-103 series total station and handheld Trimble Nomad 1050 handheld computer to create a threedimensional point cloud. The site grid was set up using a free open source software, EDM-mobile, created by Shannon McPherron and Harold Dibble. The grid was aligned with the lakeshore with the site northing set at $340^{\circ}$. The UTM coordinates (WGS84) of the initial site datum are Zone 21M E: $530024 \mathrm{~N}$ : 9704263 with an elevation of 20 meters above sea level. In addition to the original datum, fifty-six other reference points were created around the surveyed area so the total station could be moved around and initialized in numerous different places around the site.

\section{Topography}

A stratified sampling strategy was used to map the topography of the site. Higher resolution microtopography was recorded for areas with greater surface heterogeneity, while topographically homogeneous areas were recorded at a lower resolution. Three distinct topographic strata were delineated for the site survey. The first stratum includes the ports and covers a total area of $964 \mathrm{~m}^{2}$. This area was mapped at the highest resolution with an average of $1.5 \mathrm{point} / \mathrm{m}^{2}$ because it exhibited the greatest level of surface heterogeneity at the site. The second topographically distinct stratum of the site is located just northwest of the ports and covers an area of $8,172 \mathrm{~m}^{2}$. This area exhibited variations in elevation as well as large, deep (up to $40 \mathrm{~cm}$ as evidenced by opportunistic soil probes) tracts of terra preta and numerous ceramic sherds above and below the surface. Topography was taken for this area at an average resolution of 0.25 point $/ \mathrm{m}^{2}$. 
The third and final topographically distinct stratum covered $4,856 \mathrm{~m}^{2}$ of the site and was mapped with an average resolution of 0.04 point $/ \mathrm{m}^{2}$. This area was used as a horse pasture and was relatively flat with little variation in topography.

\section{Modern Features}

Contemporary features, including three houses, a kitchen, a wooden bridge, three sheds, a chicken coop, two old foundations, a manioc field, two house gardens, fence lines, a horse pasture, a trail, a dirt road, and one paved road, were mapped to help understand possible irregularities in the topography resulting from contemporary use. All of the existing modern features, except the paved road, horse pasture, trail, and the majority of the fence line, were located within $90 \mathrm{~m}$ of the lakeshore. This $9,080 \mathrm{~m}^{2}$ area was the main open-air portion of the site. Hand drawn maps were also created to document the features, vegetation, and layout of the site. Conversations with owners of the property added to our knowledge of recent site use and contemporary landscape utilization.

\section{Data Processing}

Point cloud data were exported from the Trimble handheld computer as an ASCII file, converted to CSV format, and then processed in ArcGIS version 10.6.1 (ESRI 2018). Topographic points and points associated with modern features were separated into different CSV files and then individually imported into ArcMap. The X, Y, and Z was defined based on information stored in the point data and the projection set to UTM zone 21 south for each CSV file. Once the X, Y, Z was defined and the projection set, each CSV file was exported as a feature class within a larger site geodatabase. From there, 
points were processed to create topographic maps of the site and outline the extent of modern features.

In order to represent the topography of the site, a Digital Elevation Model (DEM) was created by interpolating elevation points using Nearest Neighbor. Numerous other datasets were derived from the DEM using the Spatial Analyst tool in ArcMap, including contour lines and a slope raster.

Modern features were represented by creating lines and polygons using the Editor tool in ArcMap. The outline and extent of these features was determined based on the location information stored in the point data. 


\section{CHAPTER 5: RESULTS}

The survey at Macurany identified two site boundaries and four types of distinct pre-Columbian landscape features, including ports, middens, terra preta and anthropogenic forests. The southeast boundary of the site is defined by the shores of Lake Parananema. The habitation zone of the site extends northwest about 200 meters from the lakefront with areas of utilized landscape extending 600 meters from the habitation zone to where the Vila Cristina neighborhood is located. The southwestern and northeastern boundaries of the site were unidentified because the site is located on privately owned property with limited access.

Anthropogenic topographical features (Figure 4) were distributed as follows: the ports line the southeastern boundary of the site and cover an area of $964 \mathrm{~m}^{2}$, providing direct access to Lake Parananema. The middens are located just northwest of the ports and extend for 7,660 $\mathrm{m}^{2}$. The midden area is also where the largest tracts of terra preta are located. Anthropogenic forests enclose the open air portion of the site on the northwestern and northeastern boundaries, covering an area of approximately $65,365 \mathrm{~m}^{2}$. Modern features were concentrated towards the southeast boundary of the surveyed area with the majority of the structures built within $90 \mathrm{~m}$ of the shoreline, which seems to coincide with ancient habitation areas. 

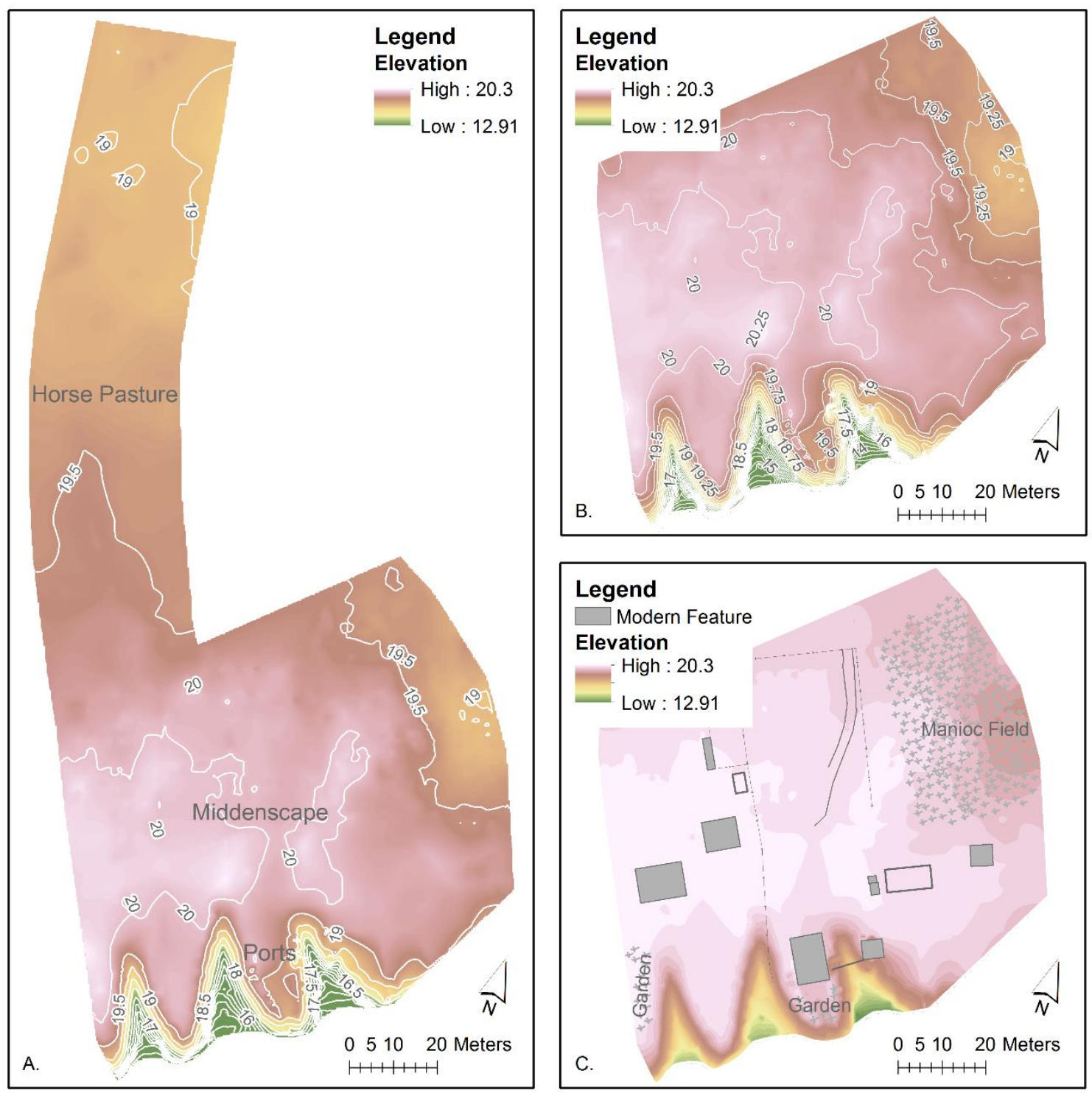

Figure 4. (A) Extent of topographically mapped area with $50 \mathrm{~cm}$ contours. (B) Topography of middens and ports with $25 \mathrm{~cm}$ contours. $(C)$ Topography of middens and ports with modern features. 


\section{$\underline{\text { Ports }}$}

Three earthen ports were identified and mapped during the survey (Figure 5).

Each port has a footpath that leads down to the water from the bluff creating a V-shaped structure. The trampling from foot traffic has compacted the earth below creating an unnaturally smooth and straight path. The sides are extremely steep and mostly covered
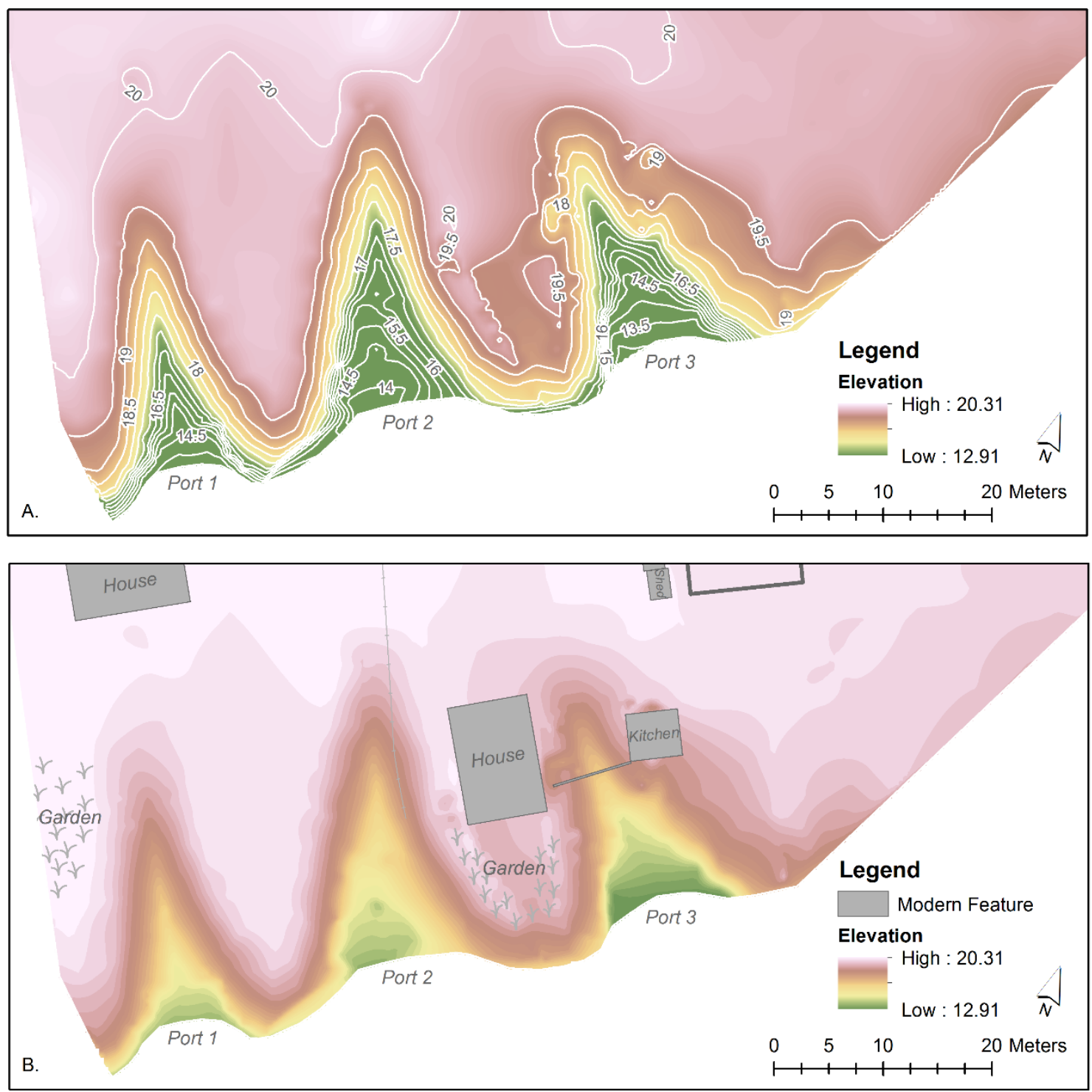

Figure 5. (A) Topography of ports at Macurany with 50cm contours. (B) Topography of ports at Macurany with $25 \mathrm{~cm}$ contour and modern features. 
in vegetation making them un-walkable. The compacted, trampled foot paths and steep, vegetation covered slopes help preserve the shape of the sculpted earthen ports by directing the flow of rainwater runoff, which prevents the slopes from eroding and natural rills to form, and also help stabilize the bank of the lake bluff.

The ports are regularly spaced about 15 meters apart along the northwest shore of the lake and exhibit little variation in size and slope (Table 1). The results indicate Port 2 is the largest measuring $29 \mathrm{~m}$ in length, 21 $\mathrm{m}$ in width at the shoreline, and covering an area of $387 \mathrm{~m}^{2}$. The second largest port is Port 3 measuring $24 \mathrm{~m}$ in length, $18 \mathrm{~m}$ in width along the shoreline, and covering an area of $297 \mathrm{~m}^{2}$. Port 1 is only slightly smaller than Port 3 measuring $24 \mathrm{~m}$ in

\begin{tabular}{r|ccc}
\multicolumn{1}{c}{} & Port 1 & Port 2 & Port 3 \\
\hline Length & $24 \mathrm{~m}$ & $29 \mathrm{~m}$ & $24 \mathrm{~m}$ \\
Width & $14 \mathrm{~m}$ & $21 \mathrm{~m}$ & $18 \mathrm{~m}$ \\
Area & $280 \mathrm{~m}^{2}$ & $387 \mathrm{~m}^{2}$ & $297 \mathrm{~m}^{2}$ \\
Slope & $6^{\circ}$ & $9^{\circ}$ & $13^{\circ}$
\end{tabular}
length, $14 \mathrm{~m}$ in width along the lakefront, and Table 1.Measurements of ports surveyed at Macurany. covering an area of $280 \mathrm{~m}^{2}$. The port with the steepest footpath leading down towards the water is Port 3 with an average footpath slope of $13^{\circ}$, followed by Port 2 with an average slope of $9^{\circ}$, then Port 1 with an average slope of $6^{\circ}$.

Port 1 exhibits the highest degree of preservation, followed by Port 2, then Port 3. Port 1 was frequently used by site inhabitants during the time of our survey for docking boats and playing (Figure 6). The owners also maintained a garden on the area of land 
between Port 1 and the port located to the southwest, which does not seem to have affected the original topography of the port (Figure 7).

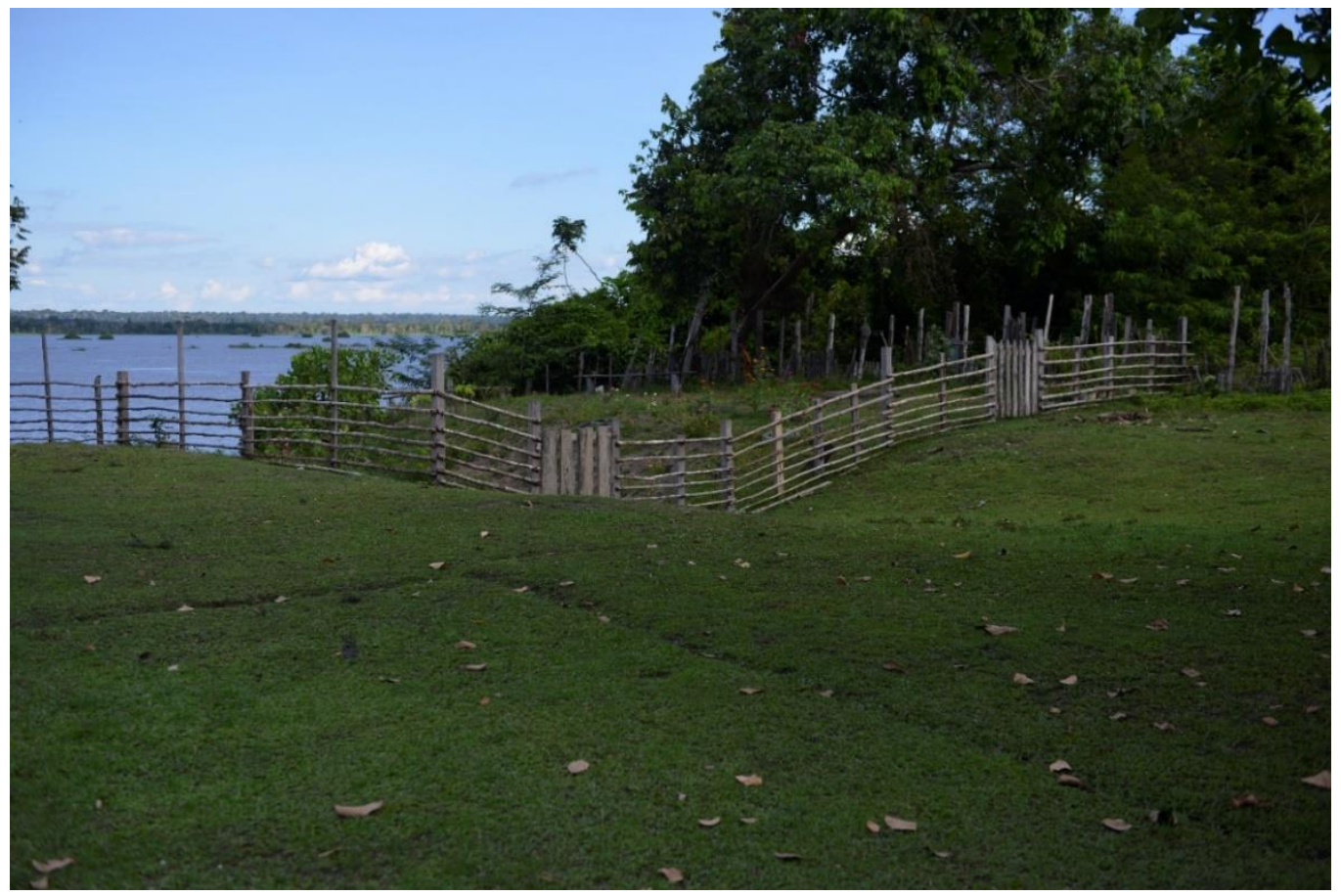

Figure 6. Southwest view of Port 1 and garden on bluff. Photo taken by Anna Browne Ribeiro.

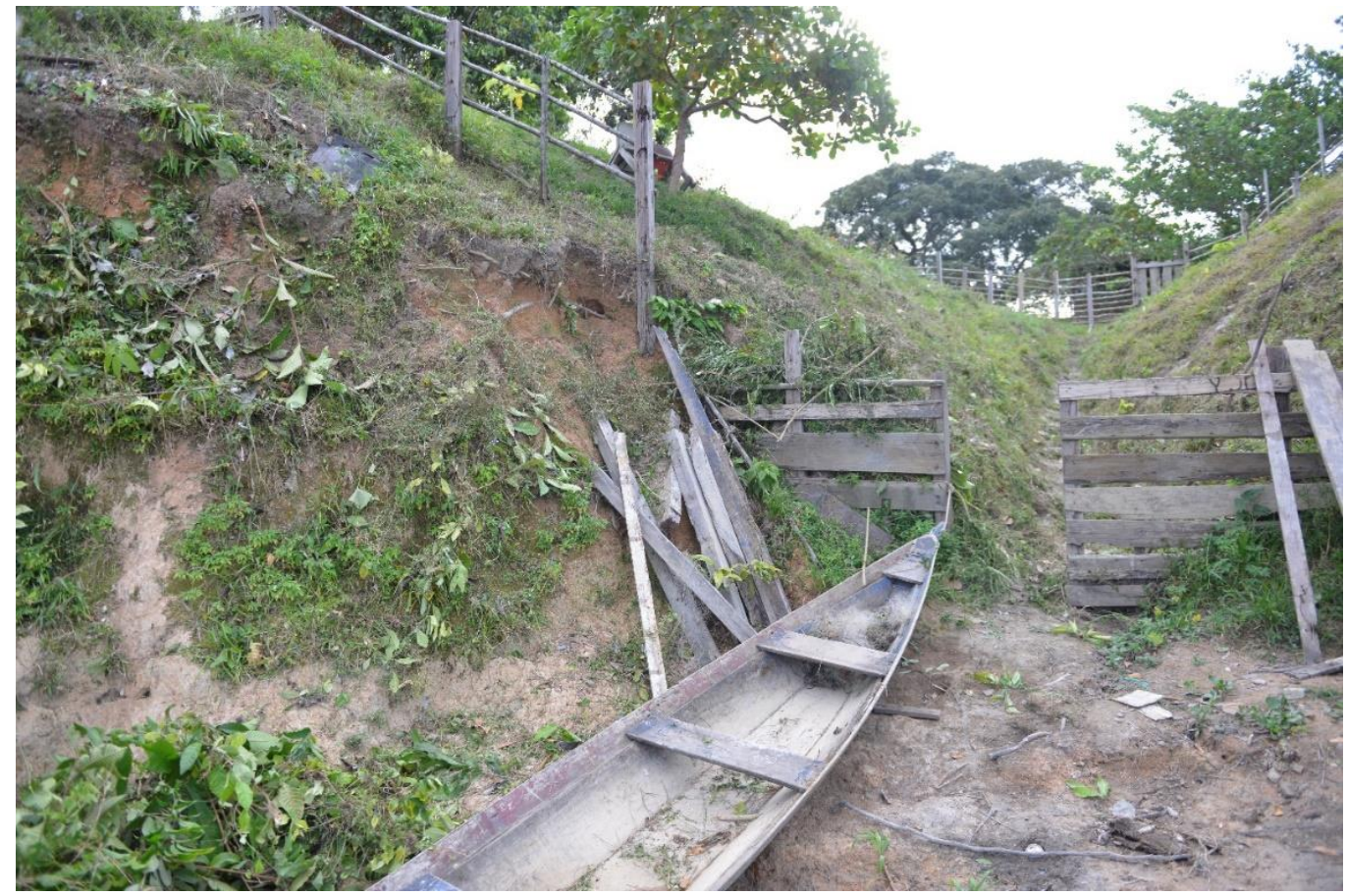

Figure 7. Northwest view of Port 1 from lakeshore. Photo taken by Anna Browne Ribeiro. 
Port 2 was the least used by contemporary site inhabitants during the time of our survey, even though it was the largest port surveyed (Figure 8). A contemporary house/workshop and garden are located on the bluff between Port 2 and Port 3 (Figure 9), which seems to have eroded the original topography of that area of land and the southwestern side of Port 3.

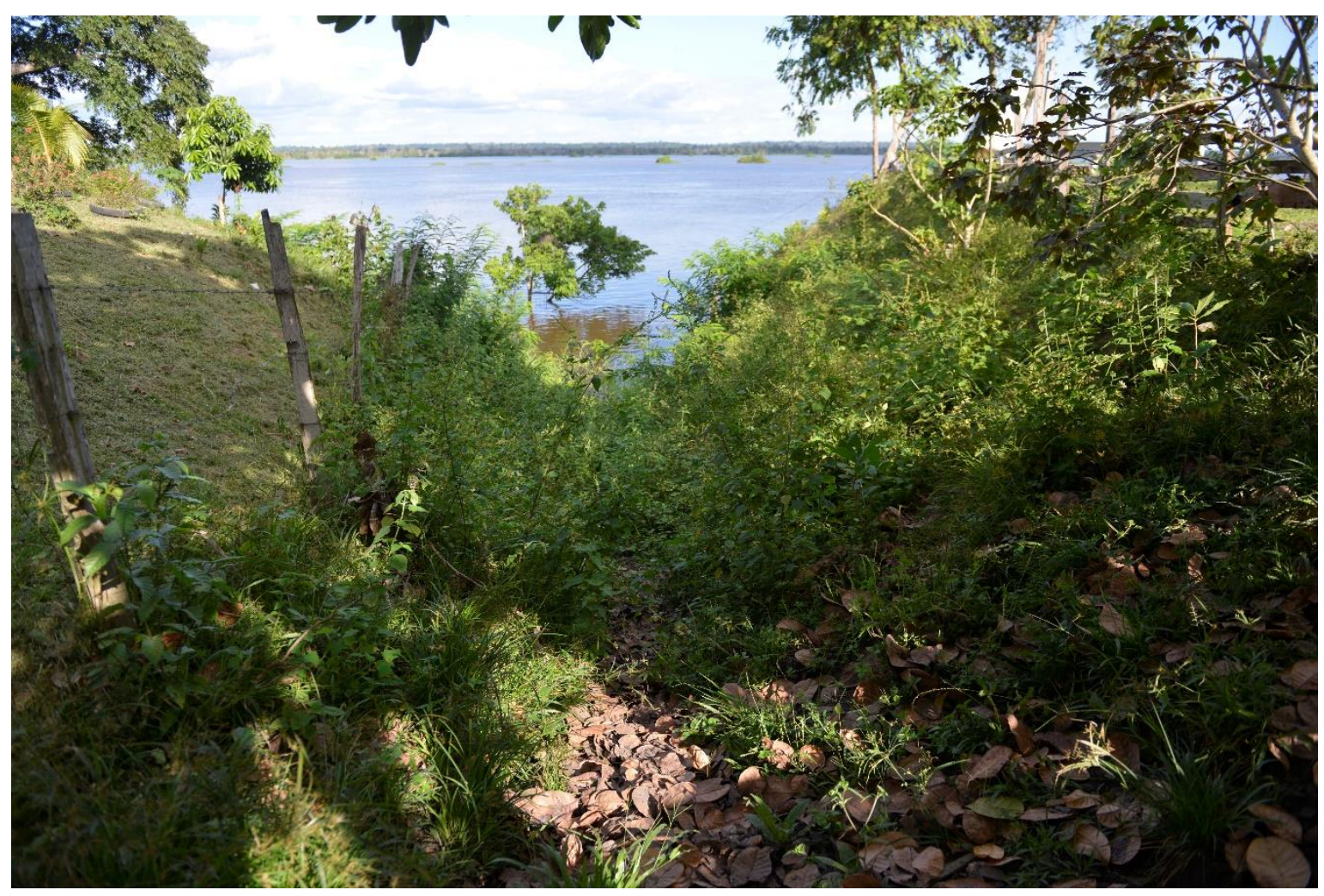

Figure 8. Southeast view of Port 2. Photo taken by Anna Browne Ribeiro. 


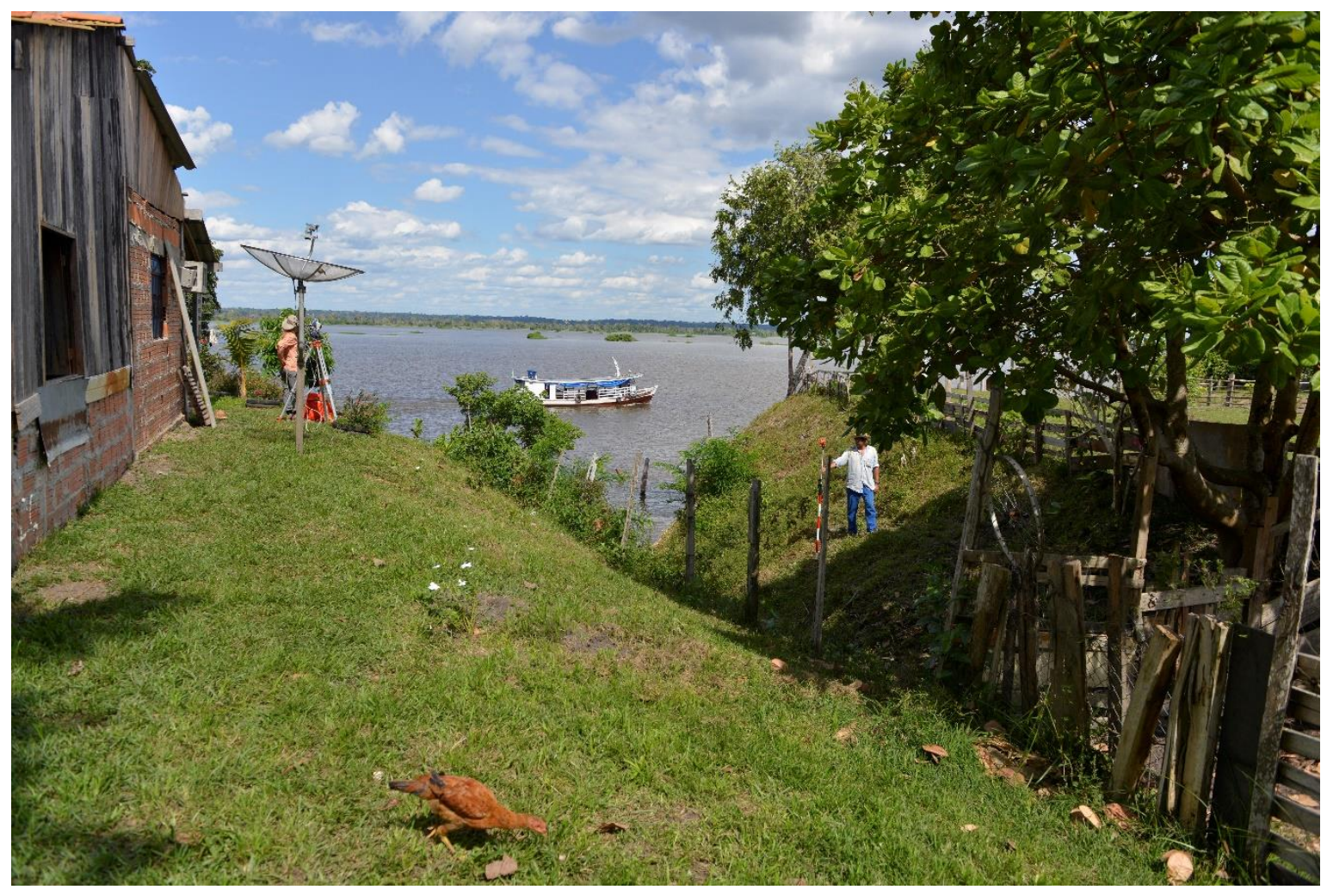

Figure 9. South view of Port 2 with house constructed on bluff. Photo taken by Anna Browne Ribeiro.

Port 3 was the most heavily used of all the ports surveyed and seems to have suffered the most degradation due to contemporary use (Figure 10). The topographic irregularities of Port 3 indicate heavy erosion on the southwestern and northeastern slopes, which were most likely caused by the construction of a bridge over the port and use of modern features (Figure 11). 


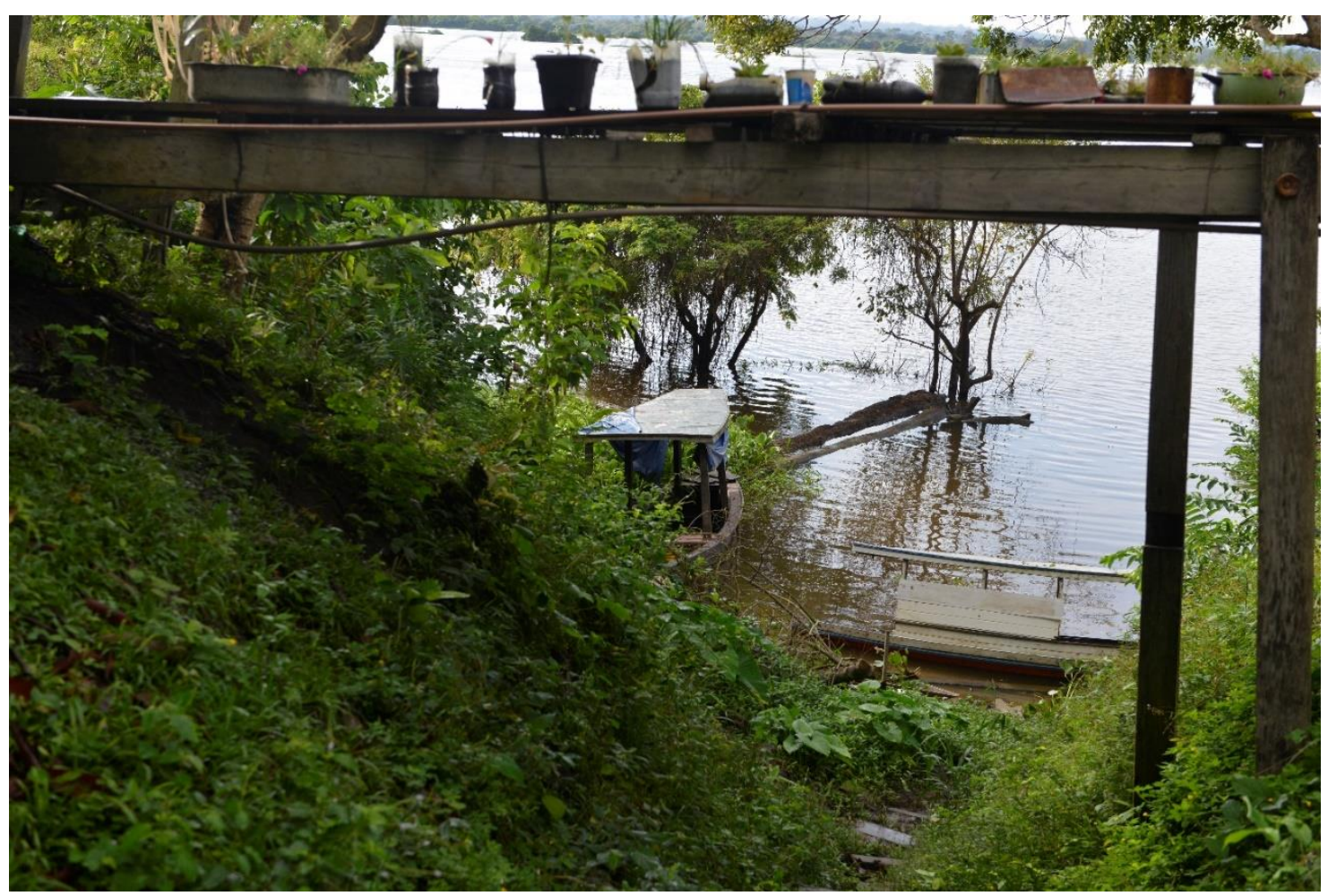

Figure 10. Southeast view of Port 3. Photo taken by Anna Browne Ribeiro.

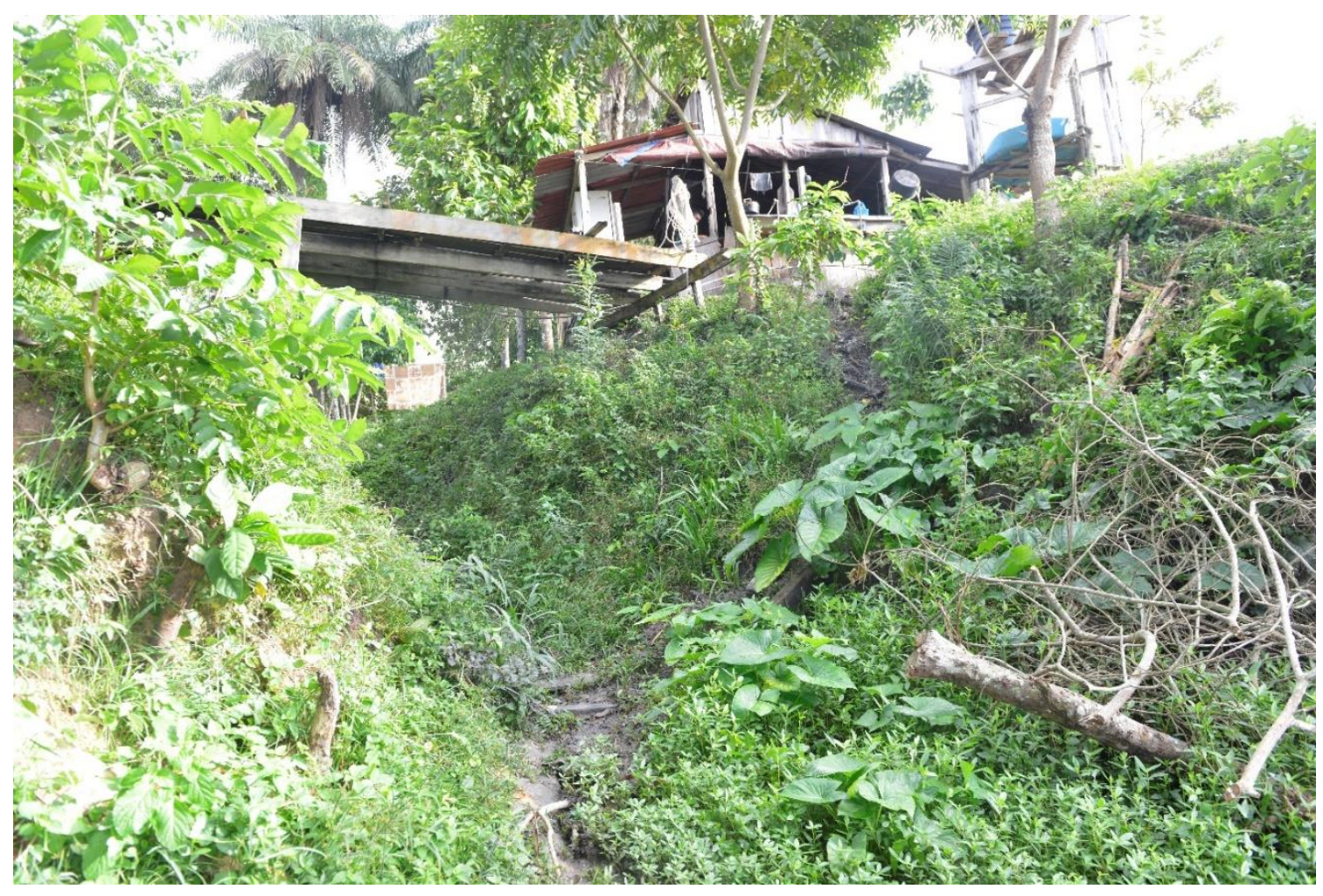

Figure 11. Northeast view of Port 3. Photo taken by Anna Browne Ribeiro. 


\section{$\underline{\text { Middens }}$}

Topographic data show the presence of elevated areas concentrated along the southeastern extent of the site close to the ports and lakeshore, covering an area of approximately 7,660 $\mathrm{m}^{2}$ (Figure 12). Due to the topography, soil composition, and high frequency of ceramics observed eroding out of elevated areas, this area was identified as a middenscape. The middens are irregularly shaped and vary significantly in elevation. The highest elevation in this area is recorded at $20 \mathrm{~m}$ above sea level, with the lowest elevation recorded at $18 \mathrm{~m}$ above sea level. Some topographic irregularities in this area are associated with modern use. A contemporary dirt road has cut through the middenscape leaving a linear, half meter-deep impression in the surface and possibly enhancing elevation on either side of the road. Additionally, houses and other heavily trafficked areas appear to have disturbed the original topography of the middenscape (Figure 12). 

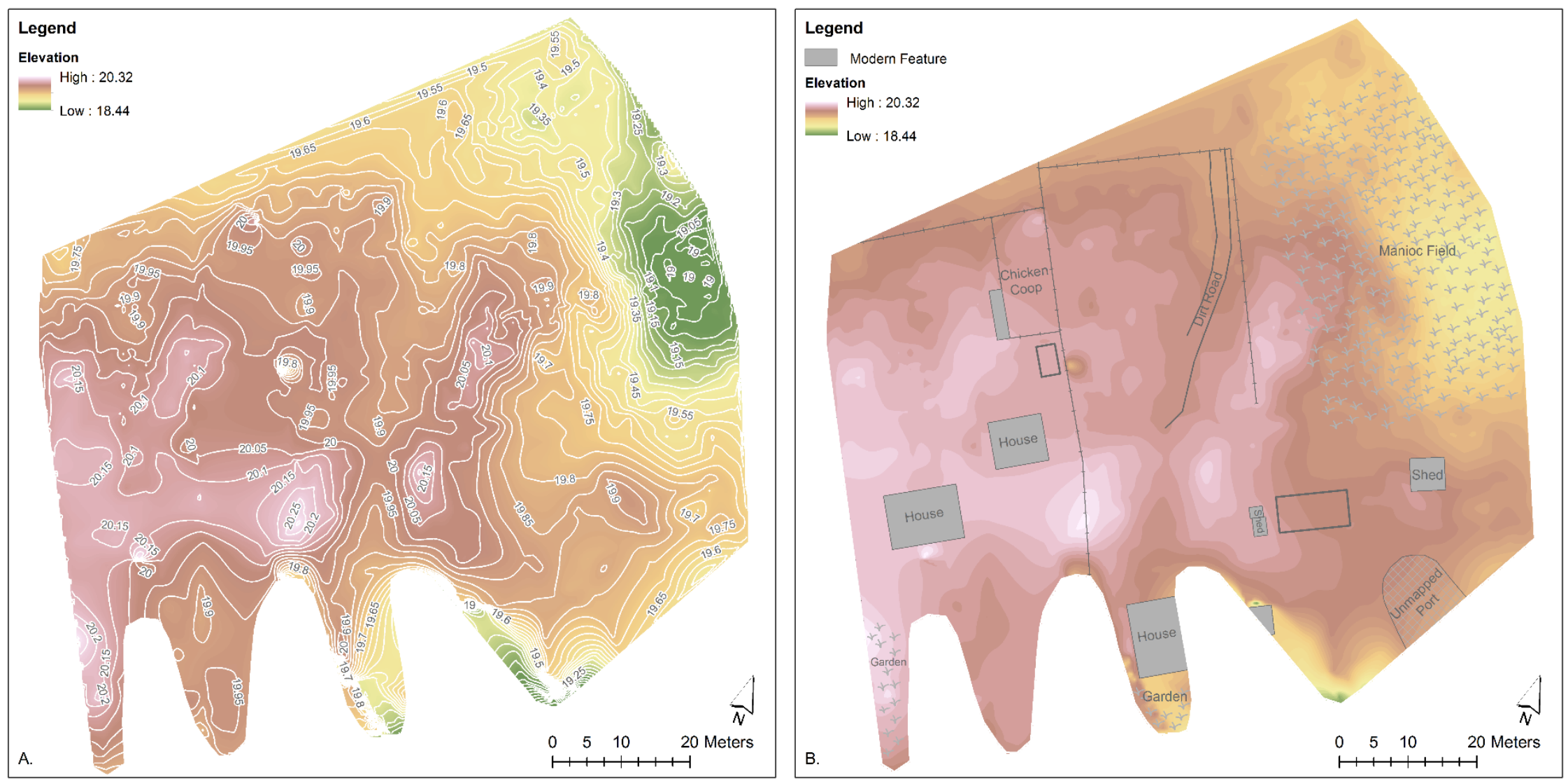

Figure 12. (A) Topography of middenscape at Macurany with $5 \mathrm{~cm}$ contours. (B) Topography of middensacpe at Macurany with modern features. 


\section{$\underline{\text { Terra Preta }}$}

The distribution of terra preta varies across the site. The most intensely modified terra preta is located within the middenscape. The elevation, and likely thickness, of terra preta decreases across surveyed area of the site as it approaches the Brazil nut stand to the northwest.

\section{$\underline{\text { Anthropogenic Forests }}$}

Anthropogenic forests at

Macurany are dominated by Brazil

nut trees and mixed managed forests (Figure 13). Brazil nut (Bertholetia excelsia) stands are located along the northwest and northeast perimeter of the surveyed area. Mixed managed forests are situated closer to domestic areas of the property, including inajá (Attalea maripa), cashew (Anacardium occidentale), guava (Psidium guajava), genipapo (Genipa Americana), acerola (Malpighia emarginata)

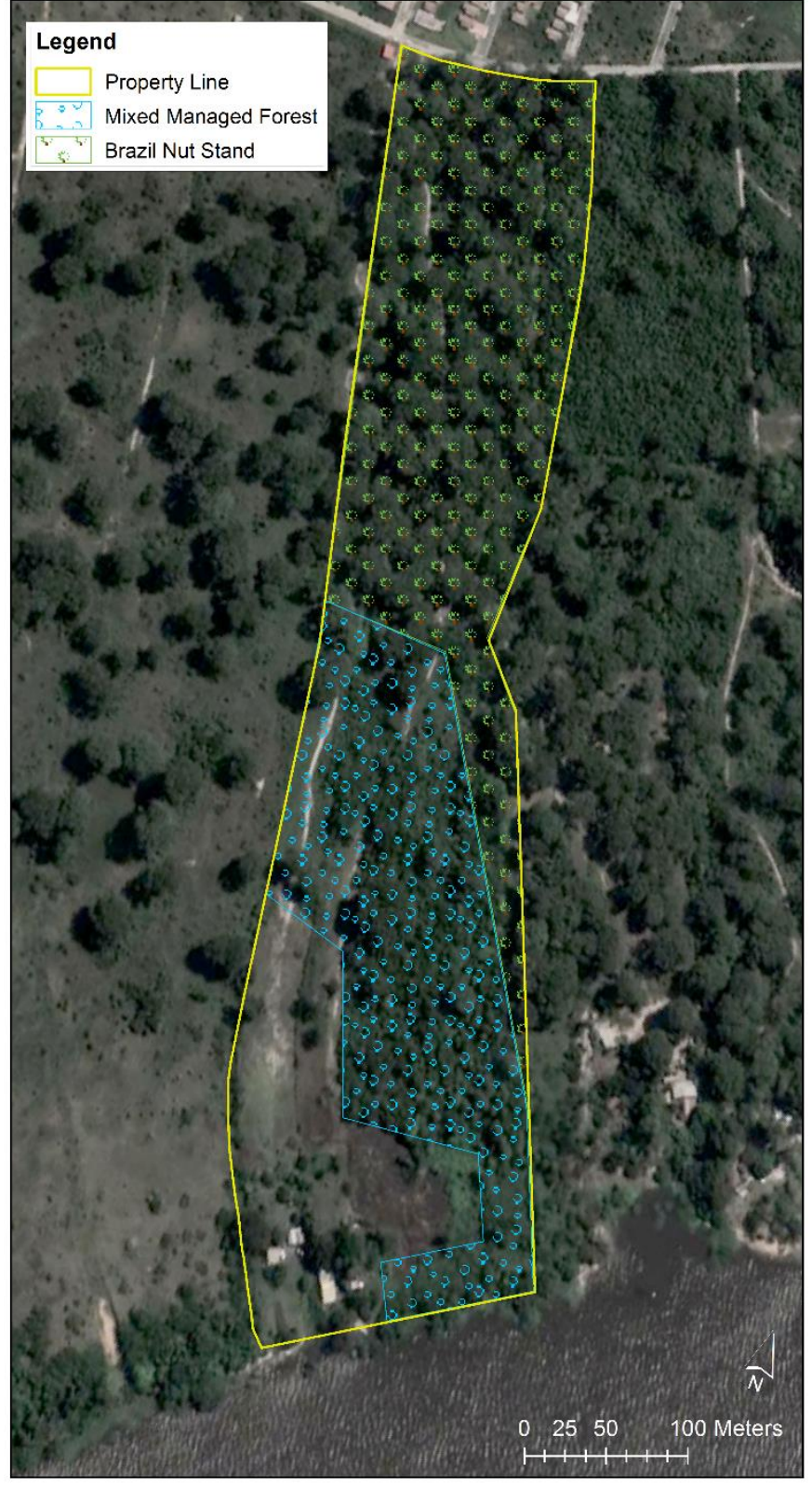

Figure 13. Distribution of anthropogenic forests at Macurany.

and various palm and fruit tree species. Residents report actively managing the Brazil nut stands and palms, regularly burning plant debris and harvesting fruit. 


\section{CHAPTER 6: DISCUSSION}

The survey conducted at Macurany revealed settlement, subsistence, and infrastructural landscapes composed of four distinct classes of pre-Columbian landscape features: ports, middens, terra preta, and anthropogenic forests. Geospatial analysis of landscape features at Macurany helped identify spatial patterns and relationships among features at the site in order to understand how these landscapes were formed and how they illuminate past human behavior and spatial organization.

\section{Spatial Patterning of Landscape Features}

The spatial patterning of the ports at Macurany is highly regularized (Figure 5). Although there is slight variation in size, the structure of the ports is uniform. Additionally, the placement and orientation of the ports is very standardized along the shore of the lake. Each port opens up towards the lake with a moderately sloping footpath leading down to the water surrounded on two sides with much steeper, un-walkable bluff edges. Unlike naturally occurring rills caused by erosion, as seen in Figure 11, the compacted, straight paths and smooth, steep slopes suggest the earthen ports are anthropogenic.

The ports lead from the lake up to the midden area, which is also concentrated towards the edge of the bluffs. However, unlike the ports, the middenscape exhibits a 
very irregular pattern (Figure 12). Areas of high and low elevation are inconsistent across space and the middens yielded no identifiable pattern across the surveyed area. It is possible that current and historical features may be obscuring the patterning of the middens at the site. Enlarging the survey area may yield comprehensible patterns.

Terra preta varies in depth and distribution across the site, as indicated by opportunistic probes and anecdotal data from residents. The deepest and most widely distributed tracts of terra preta coincide with the midden area. Terra preta seems to decrease in depth and fades out beyond the horse pasture, although this has not been pinpointed with precision. The last identified signs of habitation were found about 200 meters northwest from the lakeshore.

Anthropogenic forests emerge around the boundaries of the middenscape and increase in density towards the northeastern and northwestern boundaries of the site (Figure 13). Brazil nut stands dominate the northern perimeter of the site with mixed managed forests appearing closer towards the midden area and along the southeast site boundary. Narratives from local residents suggests the Brazil nut stands may have been more extensive, but no formal interview data was gathered.

\section{$\underline{\text { Landscape Formation Processes }}$}

Geospatial analysis of the ports and their frequency, regularity, and association with terra preta, suggests they are the result of intentional anthropogenic activities. The ports would have functioned as infrastructural landscape features that were built into the lake bluff at regular intervals providing site inhabitants with access to aquatic resources and communication and trade routes. The ports would have been maintained through 
daily use, as abandoned ports that were observed during survey exhibited erosion and were densely vegetated, making them impassable and unusable.

Current use of the site is still contributing to the formation of these landscape features. Modern use of a bridge constructed across Port 3 seems to have disturbed the original structure resulting in a much steeper footpath and heavily eroded and irregular sides (Figure 11). The fact that ports with contemporary structures built on the bluffs have experienced significant erosion while ports absent of modern structures exhibit less erosion, as shown in Figure 5, suggest earlier inhabitants did not construct houses or permanent structures in those areas. The same observations about landscape preservation could have been made by pre-Columbian inhabitants, who would most likely have chosen to construct their homes in areas that would not erode the ports. Had this not been the case, the ports would not be so regular or identifiable as they are today. Instead, the bluff areas overlooking the lake could have been used as gardens, which based on observations of contemporary use, is less detrimental to the structure of the ports. Additionally, the terra preta soils available along river and lake bluffs and protected spaces the ports create would make ideal locations for house gardens.

Geospatial analysis confirmed the relationship between the middens and terra preta at Macurany. These landscape features are the result of human settlement and occupation at the site. Although these features may represent structured deposition of refuse, the formation of middens and terra preta into a sculpted soilscape may not have been intentional, as no clear spatial pattern has yet been identified. More information is required to understand the intentionality behind the formation of the middenscape at the 
site. Excavation would aid in delineating areas of habitation from areas of refuse and provide a clearer understanding of the morphology of the middenscape at Macurany.

The topographic inconsistencies of the middenscape could be the result of ancient settlement reorganization, contemporary site use, or a combination of both. Long term or repeated occupation and internal settlement restructuring at Macurany could have resulted in the inconsistent patterning of the middens. As the population increased, decreased, or moved across the landscape, the pattern and deposition of refuse around domesticated areas would change accordingly, resulting in a complex arrangement of houses and middens eventually creating a middenscape (Erickson 2003).

The middenscape has also been disturbed by recent site use. Modern features, including a dirt road, two old foundations, two houses, and a kitchen have cut across the middenscape leaving impressions in the land surface and altering the original topography of the site. It is clear that a combination of modern site use and ancient settlement reorganization have contributed to the morphology of the middenscape as it exists today at Macurany.

Ancient and modern use of the site have also affected the state of the forest surrounding Macurany. Local accounts of earlier land cover suggest these forests were once more extensive. As mentioned earlier, Brazil nut stands have also been found in association with other sites in Amazonia (Balée 1989; Conklin 2001). This evidence suggests that ancient Macurany inhabitants were actively managing the surrounding forests, which was most likely an integral part of their subsistence system (Neves 2016). This is also true for contemporary site inhabitants who practice forest management by 
collecting fresh Brazil nuts for consumption and gathering empty shells for kitchen fuel.

In the previous generation, Brazil nuts were harvested for sale at local markets.

\section{$\underline{\text { Social Organization at Macurany }}$}

The spatial patterning of ports at Macurany suggests spatial organization at the site was decentralized (Figure 14). The size, frequency and distribution of ports points to a decentralized community with each house or a group of houses having individual access to a port and possibly maintaining house gardens on the protected bluffs between the ports. Additionally, the wide distribution of resources across the landscape at the site supports the idea of decentralized subsistence and economy. The location and frequency of Brazil nut stands and palm and fruit tree species around the site suggests forest management was intensive, and that these

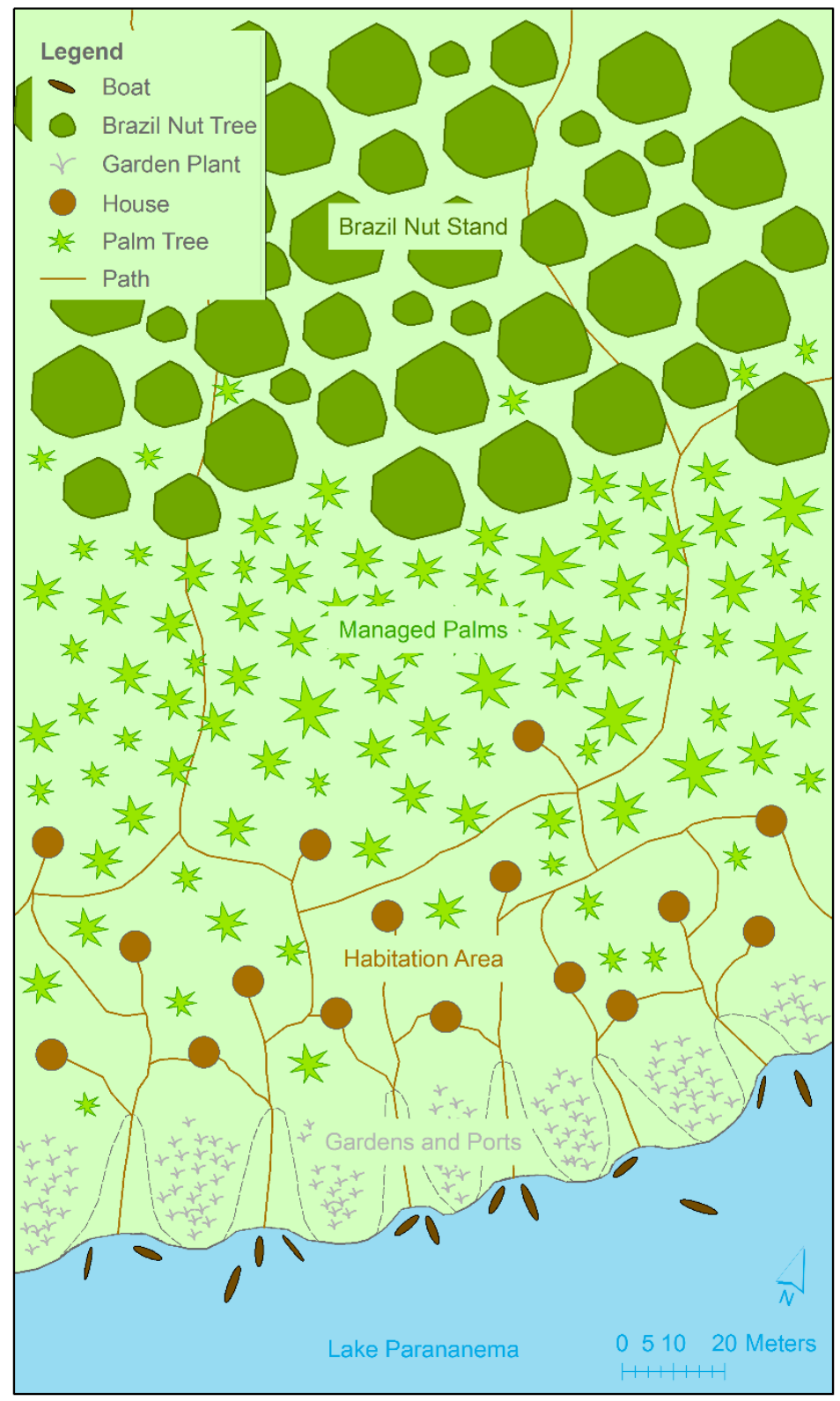

Figure 14. Possible reconstruction of Macurany.

may have been resources that all inhabitants of the site could access. The spatial 
patterning of ports and anthropogenic forests of today, if representative of forests of the past, would have given pre-Columbian inhabitants of Macurany equal access to terrestrial and aquatic resources and routes of communication and trade.

Social organization at Macurany could not be gleaned from the spatial patterning of terra preta and middens at the site because the area surveyed was not large enough and the middens not sufficiently well defined to draw conclusions about social organization. Moreover, modern use of the site has significantly modified the original topography of the middenscape making it difficult to determine pre-Columbian social organization based on the morphology and spatial patterning of the middens in the sampled area alone. However, these landscape features do indicate the presence of a permanent and densely settled society occupying the site in pre-Columbian Amazonia. Expanding the survey area could shed light on the extent of and relationship between landscape features at the site. Additionally, excavations would make it easier to understand the depth and distribution of terra preta and artifacts at the site, which would help identify the location of houses at Macurany.

\section{$\underline{\text { Regional Comparisons }}$}

This evidence helps situate Macurany within the broader regional landscape. The location of Macurany on a lake bluff matches the description of many site locations in the region. The landscape features observed at the site, such as middens, terra preta and anthropogenic forests, have been observed as sites across the region as well, but welldefined, surviving ports, especially at this frequency, seem to be a unique landscape feature to Macurany. The formation of terra preta and the middens seem to align more 
closely with formation processes observed in the Central Amazon region than the Lower Amazon. However, it is difficult to determine whether the morphology of the middens at Macurany is similar to the ringed or linear shaped pattern common in Central Amazonian villages.

In terms of social organization, Macurany seems to align more closely with the decentralized regional polities of the Central Amazon than the socially stratified, centralized hierarchical polity found in the Lower Amazon around Santarem. This evidence suggests Macurany was probably more culturally similar to societies in the Central Amazon than the Lower Amazon, following similar landscape management practices and maintaining no centralized authority or institutionalized social inequality.

However, Macurany is distinct from both regions due to the distribution and preserved state of ports. This set of infrastructural landscape features is, thus far, unique to Macurany, and represent advanced and possibly planned landscape engineering and possibly indicate a type of urbanization. It is possible that Macurany represents an entirely different regional polity in this region of Amazonia that has not previously been studied or detected in the surrounding region. The area where Macurany is located is ecologically and geographically different from other regions and may represent a completely different kind of settlement than the majority studied thus far. It could also be the case that Macurany is a peripheral node in a much larger regional polity, like that of Central Amazonia, that has similar social organization, but practice variations of landscape modification based on access to resources and environmental contexts. Similarly, it could be a node in the large tributary economy of a society like that seen at Santarém. Finally, Macurany could have been a hub for trade and export, like most port 
towns are in the world. The central location between two major regional polities would make Macurany an ideal location for a trade outpost. The location on a lake near a major river also makes it an attractive, safe space for trade to take place. Schaan (2011) claimed manmade canals connecting lakes to main rivers would trap fish in lakes, but they could also provide routes of access into and out of lake settlements and trading posts, like Macurany. The presence of large Brazil nut stands also points to some kind of export because the yield would be more than the Macurany village could consume (Neves 2016). They may have been grown and managed for export to major cities in the surrounding region.

Overall, Macurany represents a permanently and densely settled, and possibly decentralized community, intensively modifying the landscape in pre-Columbian Amazonia. The sheer number and proximity of ports and the density and extent of Brazil nut stands suggests dense, aggregated populations producing food, especially Brazil nut, far beyond their needs. The surplus of Brazil nuts suggests Macurany may have been a hub for trade. This understanding of ancient Amazonian societies challenges Western perceptions of urbanization where centralization is a requirement and changes our understanding of landscape management, infrastructure and early urbanization in Amazonia. 


\section{CHAPTER 7: CONCLUSION}

Macurany represents an understudied context in Amazonia, a low-lying, ancient

floodplain, interfluvial region between two known major centers along the main course of the Amazon River, where knowledge of pre-Columbian human-environment interaction is limited. Archaeological research at Macurany demonstrates pre-Columbian inhabitants of this region were practicing a variety of complex subsistence, settlement, and infrastructural activities that formed distinct, identifiable, and lasting features in the landscape.

Methodologically, this research demonstrates the potential of landscape features as units of archaeological investigation in Amazonia. Anthropogenic landscape features are the product of daily performances and activities carried out by human agents that become materialized in the landscape preserving and reflecting past human-environment interaction. This makes them significant sources of archaeological information, similar to traditional units of analysis, such as lithics, ceramics, or stone and masonry architectural features.

Geospatial analysis of the spatial patterning of landscape features identified at Macurany indicates that social organization of pre-Columbian inhabitants was decentralized. The frequency and size of the ports and thickness of terra preta also suggest dense, permanent habitation at the site. Intensive landscape modification coupled 
with permanent, dense settlement suggests urbanization at Macurany (Heckenberger 2008). More information about spatial and social organization at Macurany could be gleaned from enlarging the sample area and collecting more topographic data to get a better picture of the morphology of the middenscape and frequency and distribution of ports at the site. Excavations and soil probes would also contribute to our understanding of the actual formation of the middenscape because surface morphology has limited utility in zones that present recent surface disturbance.

The archaeological evidence at Macurany supports a different model of habitation and land use that does not necessitate centralized social organization for permanent landscape modification and urbanization. Macurany is evidence of a society that was managing fluvial and terrestrial resources in a way that permitted dense, urban settlement that lasted long enough to permanently modify the landscape.

Finally, this research recognizes the presence of infrastructural landscapes in preColumbian Amazonia. Amazonian archaeologists studying landscapes tend to focus on landscapes of subsistence and settlement, but as the archaeological evidence of ancient landscape modification in Amazonia increases, it becomes clear that pre-Columbian societies were much more involved with managing the landscape for reasons beyond subsistence and settlement. Infrastructural landscapes provide the necessary structure for large scale populations, regional polities and urbanization. Conversations revolving around infrastructural landscapes rarely mention Amazonia, likely due to the fact that Amazonian cultures have not been traditionally associated with social complexity and urbanization. The ports evidenced at Macurany add to the growing evidence of 
infrastructural landscape features in Amazonia and provide a unique dataset for understanding settlement organization, and urbanization more broadly.

This research contributes towards an understanding of human-environment interaction, landscape formation processes, settlement organization, and urbanization in pre-Columbian Amazonia. It sheds light into an intensively modified landscape that seems to call into question traditional assumptions about food scarcity in Amazonia, as well as the nature of economies in this region. Macurany adds yet another layer of complexity to our understanding of settlement, subsistence, production, and landscape management in ancient Amazonia, suggesting the polities in this region may have been more multi-faceted than hitherto hypothesized, calling for more and deeper scrutiny of this intermediate region. It also calls into question assumptions about urbanization and its possible forms, suggesting that Amazonia, yet again, has much to contribute to our understanding of fundamental anthropological questions. 


\section{REFERENCES}

Arroyo-Kalin, Manuel. 2017. “Amazonian Dark Earths.” In Archaeological Soil and Sediment Micromorphology, edited by C. Nicosia and G. Stoops, pp. 345-357. New York: Wiley and Sons.

--------2014. “The Variability of Amazonian Dark Earths: Comparing Anthropogenic Soils from Three Regions of the Amazonian Biome." In: Antes de Orellana, edited by Stephen Rostain. Actas del 3er Encuentro Internacional de Arqueología Amazónica. Quito: IFEA/FLACSO/US Embassy. 181-189. ISBN 978-9942-13892-7. Pp. 323-327.

2010. "The Amazonian Formative: Crop Domestication and Anthropogenic Soils.” Diversity 2 (4): 473-504. doi:10.3390/d2040473.

Aston, M. 1997. Interpreting the Landscape: Landscape Archaeology and Local History. London: Routledge.

Balée, W. 2010. "Contingent Diversity on Anthropic Landscapes." Diversity 2 (2):163181. doi: 10.3390/d2020163.

--------2013. Cultural forests of the Amazon a historical ecology of people and their landscapes. Tuscaloosa: University of Alabama Press.

--------1993. "Indigenous Transformation of Amazonian Forests: An Example from Maranhão, Brazil." L'Homme 33, no. 126/128: 231-54.

-------1989. "The culture of Amazonian forests." Resource management in Amazonia: Indigenous and folk strategies, edited by D. A. Posey and W. Balée, pp. 1-21. New York Botanical Gardens, New York.

Barrett, John C. 1999. “Chronologies of Landscape.” In The Archaeology and Anthropology of Landscape, edited by Peter J. Ucko and Robert Layton, 21-30. London: Routledge.

Bender, Barbara. 2002. "Time and Landscape." Current Anthropology 43 (S4):S103S112. doi: 10.1086/339561.

Blatrix, Rumsaïs, Bruno Roux, Philippe Béarez, Gabriela Prestes-Carneiro, Marcelo Amaya, Jose Luis Aramayo, Leonor Rodrigues, Umberto Lombardo, Jose Iriarte, Jonas Gregorio de Souza, Mark Robinson, Cyril Bernard, Marc Pouilly, Mélisse 
Durécu, Carl F. Huchzermeyer, Mashuta Kalebe, Alex Ovando, and Doyle McKey. 2018. "The unique functioning of a pre-Columbian Amazonian floodplain fishery." Scientific Reports 8 (1).

Bourdieu, Pierre. 1977. Outline of a theory of practice, Cambridge studies in social anthropology; 16. Cambridge: Cambridge University Press.Browne Ribeiro, Anna. 2017. "A Fine-Grained Analysis of Terra Preta Formation Understanding Causality Through Microartifactual and Chemical Indices in the Central Amazon." In The Archaeology of Human-Environment Interactions: Strategies for Investigating Anthropogenic Landscapes, Dynamic Environments, and Climate Change in the Human Past, edited by Daniel A. Contreras, 165-194. London: Routledge.

--------2014. "Houses, hearths, and gardens: space and temporality in a pre-Columbian village in the Central Amazon." In: Antes de Orellana, edited by Stephen Rostain. Actas del 3er Encuentro Internacional de Arqueología Amazónica. Quito: IFEA/FLACSO/US Embassy. 181-189. ISBN 978-9942-13-892-7. Pp. 183-189. -2011. "Acts, practices, and the creation of place: Geoarchaeology of a Terra Preta de Índio site in the Central Amazon." PhD dissertation, University of California, Berkeley.

Browne Ribeiro, Anna T, Helena P Lima, Fernando L. T Marques, Morgan J Schmidt, and Kevin S McDaniel. 2016. "Results from Pilot Archaeological Fieldwork at the Carrazedo Site, Lower Xingu River, Amazonia." Latin American Antiquity 27 (03): 318-39. doi:10.7183/1045-6635.27.3.318.

Cabral, M.P., Saldanha, J.D.M., 2008. "Paisagens arqueológicas na costa norte do Amapá.” Revista de Arqueologia SAB 2: 1-14.

Carvajal, Gaspar de. (1934) 1970. The Discovery of the Amazon. [1St AMS ed.]. New York: AMS Press.

Cavallini, Marta S., Filippo Stampanoni Bassi, and Lorena Rodíguez Gallo. 2015. "Petroglifos del Río Urubu. Rumbo a la Contextualización de un Arte Rupestre Amazónico." Arkeos 37: 567-588.

Clement, Charles R., and André B. Junqueira. 2010. "Between a Pristine Myth and an Impoverished Future." Biotropica 42 (5):534-536. doi: 10.1111/j.17447429.2010.00674.x.

Clement, C. R., W. M. Denevan, M. J. Heckenberger, A. B. Junqueira, E. G. Neves, W. G. Teixeira, and W. I. Woods. 2015. "The domestication of Amazonia before European conquest." Proceedings. Biological sciences 282 (1812):20150813. doi: 10.1098/rspb.2015.0813. 
Conklin, B. A. 2001. Consuming grief: Compassionate cannibalism in an Amazonian society. Austin: University of Texas Press.

Daniels, S., and Cosgrove, D. 1988. "Introduction: Iconography and Landscape." In The Iconography of Landscape, edited by D. Cosgrove and S. Daniels, 1-10. Cambridge: Cambridge University Press.

David, Bruno and Julian Thomas. 2008. "Landscape Archaeology: Introduction." In Handbook of Landscape Archaeology, edited by Bruno David and Julian Thomas, 27-43. Walnut Creek: Left Coast Press, Inc.

de Souza, Jonas Gregorio, Denise Pahl Schaan, Mark Robinson, Antonia Damasceno Barbosa, Luiz E. O. C. Aragão, Ben Hur Marimon Jr, Beatriz Schwantes Marimon, Izaias Brasil da Silva, Salman Saeed Khan, Francisco Ruji Nakahara, and José Iriarte. 2018. "Pre-Columbian earth-builders settled along the entire southern rim of the Amazon." Nature Communications 9 (1):1125. doi: 10.1038/s41467-018-03510-7.

Denevan, William M. 2001. Cultivated Landscapes of Native Amazonia and the Andes: Triumph Over the Soil. Oxford Geographical and Environmental Studies. Oxford: Oxford University Press.

1966. The Aboriginal Cultural Geography of the Llanos de Mojos of Bolivia. Berkley: Ibero-Americana 48.

Erickson, Clark L. 2010. "The Transformation of Environment into Landscape: The Historical Ecology of Monumental Earthwork Construction in the Bolivian Amazon." Diversity 2: 618-653.

-------2003. "Historical Ecology and Future Explorations." In Amazonian Dark Earths: Origin, Properties, Management, edited by Johannes Lehmann, Dirse C. Kern, Bruno Glaser, and William I. Woods, pp. 455-500. Dordrecht: Kluwer Academic Publishers.

Erickson, Clark L., and William Balee. 2006. "The Historical Ecology of a Complex Landscape in Bolivia." In Time and Complexity in Historical Ecology Studies in the Neotropical Lowlands, edited by William Balee and Clark L. Erickson, 187233. New York: Columbia University Press.

ESRI. 2018. ArcGIS Desktop v10.6.1. Redlands, CA: Environmental Systems Research Institute.

Foucault, M. 1970. The Order of Things. London: Tavistock. 
Gaspar, Maria Dulce, Paulo DeBlasis, Suzanna K. Fish, and Paul R. Fish. 2008. In Handbook of South American Archaeology, edited by Helaine Silverman and William H. Isbell, 319-335. New York: Springer.

Glaser, B, and William I Woods. 2004. Amazonian Dark Earths: Explorations in Space and Time. Berlin: Springer.

Hartt, Charles Frederick. 1874. Preliminary Report of the Morgan Expeditions, 1870-71.Report of a Reconnoissance of the Lower Tapajos. Bulletin of the Cornell University (Science), Vol. 1, No. 1. Ithaca, N.Y: Printed at the University Press.

Heckenberger, M. 2011. "Deep history, cultural identities, and ethnogenesis in the Southern Amazon." In Ethnicity in Ancient Amazonia: Reconstructing Past Identities from Archaeology, Linguistics, and Ethnohistory, edited by Alf Hornborg and Jonathan D. Hill pp. 57-74. University Press of Colorado, Boulder. 2008. "Amazonian Mosaics: Identity, Interaction, and Integration in the Tropical Forest." In Handbook of South American Archaeology, edited by Helaine Silverman and William H. Isbell, 941-961. New York: Springer.

Heckenberger, Michael J, J. Christian Russell, Carlos Fausto, Joshua R Toney, Morgan J Schmidt, Edithe Pereira, Bruna Franchetto, and Afukaka Kuikuro. 2008. "PreColumbian Urbanism, Anthropogenic Landscapes, and the Future of the Amazon." Science 321 (5893): 1214-17.

Heckenberger, Michael J., J. Christian Russell, Joshua R. Toney and Morgan J.Schmidt. 2007. "The Legacy of Cultural Landscapes in the Brazilian Amazon: Implications for Biodiversity.” Philosophical Transactions: Biological Sciences 362 (1478), 197-208. doi: 10.1098/rstb.2006.1979.

Hirth, K. G. 1978. "Teotihuacan regional population administration on eastern Morelos." World Archaeology 9: 320-33.

Ingold, Tim. 1993. "The Temporality of the Landscape." World Archaeology 25 (2): $152-74$.

Iriarte, José, Paulo DeBlasis, Jonas Gregorio De Souza, and Rafael Corteletti. 2017. "Emergent Complexity, Changing Landscapes, and Spheres of Interaction in Southeastern South America During the Middle and Late Holocene." Journal of Archaeological Research 25 (3):251-313. doi: 10.1007/s10814-016-9100-0.

Iriarte, José, Silvia Moehlecke Copé, Michael Fradley, Jami J. Lockhart, and J. Christopher Gillam. 2013. "Sacred landscapes of the southern Brazilian highlands: Understanding southern proto-Jê mound and enclosure complexes." Journal of Anthropological Archaeology 32 (1):74-96. doi: https://doi.org/10.1016/j.jaa.2012.10.003. 
Iriarte, José, Mitchell J. Power, Stéphen Rostain, Francis E. Mayle, Huw Jones, Jennifer Watling, Bronwen S. Whitney, and Doyle B. McKey. 2012. "Fire-free land use in pre-1492 Amazonian savannas." Proceedings of the National Academy of Sciences 109 (17):6473-6478. doi: 10.1073/pnas.1201461109.

Isendahl, Christian, Daryl Stump, and Manuel Arroyo-Kalin. 2019. "The Oxford Handbook of Historical Ecology and Applied Archaeology." Essay. In Landscaping, Landscape Legacies, and Landesque Capital in Pre-Columbian Amazonia. Oxford University Press. doi:10.1093/oxfordhb/9780199672691.013.16.

Katzer, Friedrich. 1903. Grundzüge Der Geologie Des Unteren Amazonasgebietes : (Des Staates Pará in Brasilien). Leipzig: M. Weg.

Keith, M. and Pile S. (eds.). 1993. Place and the Politics of Identity. London: Routledge.

Kern, Dirse Clara, Helena Pinto Lima, Jucilene Amorim da Costa, Herdjania Veras de Lima, Anna Browne Ribeiro, Bruno Marcos Moraes, and Nestor Kämpf. 2017. "Terras pretas: approaches to formation processes in a new paradigm." Geoarchaeology - New York: 32 (6):694-706.

Lathrap, Donald. 1977. "Our Father the Cayman, Our Mother the Gourd: Spinden Revisited, or a Unitary Model for the Emergence of Agriculture in the New World." In Origins of Agriculture, edited by Charles A. Reed, 713-751. Paris: Mouton Publishers.

--------1970. The Upper Amazon: Ancient Peoples and Places. London: Thames and Hudson.

Lehmann, Johannes, Kern, D.C., Glaser, B., and Woods, W.I., eds. 2003. Amazonian Dark Earths: Origin Properties Management. Dordrecht: Kluwer Academic.

Levis, Carolina, Marcio de Souza Silva, Mauro Almeida e Silva, Claide P. Moraes, Eduardo K. Tamanaha, Bernardo M. Flores, Eduardo Góes Neves, and Charles R. Clement. 2014. "What do we know about the distribution of Amazonian Dark Earth along tributary rivers in Central Amazonia?" In Antes De Orellana : Actas Del 3er Encuentro Internacional De Arqueología Amazónica.Edited by Stéphen Rostain and Encuentro Internacional De Arqueología Amazónica Encuentro Internacional De Arqueología Amazónica (3: 2013 : Quito), 305-311. Quito: Instituto Francés De Estudios Andinos.

Lipkind, William. 1948. "The Caraja.” In Handbook of South American Indians, edited by Julian H. Steward, 179-191. Washington D.C.: U.S. Government Printing Office. 
Lima, Hedinaldo N., Carlos E. R. Schaefer, Jaime W. V. Mello, Robert J. Gilkes, and João C. Ker. 2002. "Pedogenesis and pre-Colombian land use of "Terra Preta Anthrosols" ("Indian black earth") of Western Amazonia." Geoderma 110 (1):117. doi: https://doi.org/10.1016/S0016-7061(02)00141-6.

Lins, Juliana, Helena P. Lima, Fabricio B. Baccaro, Valdely F. Kinupp, Glenn H. JrShepard, and Charles R. Clement. 2015. "Pre-Columbian Floristic Legacies in Modern Homegardens of Central Amazonia." PLoS ONE 10 (6):1-10. doi: 10.1371/journal.pone.0127067.

Lima, Hedinaldo N, Carlos E.R Schaefer, Jaime W.V Mello, Robert J Gilkes, and Ker João C. 2002. "Pedogenesis and Pre-Colombian Land Use of 'Terra Preta Anthrosols' ('Indian Black Earth') of Western Amazonia." Geoderma 110 (1): 117. doi:10.1016/S0016-7061(02)00141-6.

Lima, Helena Pinto, Eduardo Góes Neves, and James B. Petersen. 2006. "La fase Açutuba: un novo complexo cerâmico na Amazônia central." Arqueología Suramericana/Arqueologia Sul-Americana 2(1):26-52.

Lombardo, Umberto, Katherine Szabo, José M. Capriles, Jan-Hendrik May, Wulf Amelung, Rainer Hutterer, Eva Lehndorff, Anna Plotzki, and Heinz Veit. 2013. "Early and Middle Holocene Hunter-Gatherer Occupations in Western Amazonia: The Hidden Shell Middens." PLOS ONE 8 (8):e72746. doi: 10.1371/journal.pone.0072746.

Lombardo, Umberto, and Heiko Prümers. 2010. "Pre-Columbian human occupation patterns in the eastern plains of the Llanos de Moxos, Bolivian Amazonia." Journal of Archaeological Science 37 (8):1875-1885. doi: https://doi.org/10.1016/j.jas.2010.02.011.

Lowie, Robert Harry. 1948. "The Tropical Forests: An Introduction." Handbook of South American Indians / Julian H. Steward, Ed. Vol. 3, the Tropical Forest Tribes1.

Machado, J. 2005. "Montículos artificiais na Amazônia central: um estudo de caso do sítio Hatahara." M. S. Thesis, Museu de Arqueologia e Etnologia, Universidade de São Paulo.

Marshall, A. J. 1978. "Environment and Agriculture during the Iron Age: Statistical Analysis of Changing Settlement Ecology." World Archaeology 9 (3): 347-56.

Mayle, Francis E. and Jose Iriarte. 2014. "Integrated palaeoecology and archaeology - a powerful approach for understanding pre-Columbian Amazonia." Journal of Archaeological Science 51, 54-64. Doi: http://dx.doi.org/10.1016/j.jas.2012.08.038.

McEwan, C., Barreto, C., and Neves, E. (eds.). 2001. Unknown Amazon: Culture and Nature in Ancient Brazil. British Museum: London. 
Meggers, Betty J. 1954. "Environmental Limitation on the Development of Culture." American Anthropologist 56 (5):801-824. doi: 10.1525/aa.1954.56.5.02a00060 1971. Amazonia Man and Culture in a Counterfeit Paradise. Chicago: Aldine Publishing Company.

Meggers, B. J., and C. Evans. 1957. Archeological investigations at the mouth of the Amazon. Washington, D.C.: Government Printing Office.

Merleau-Ponty. 1962. Phenomenology of Perception. London: Routledge and Kegan Paul

Moraes, C. d. P. 2007 Arqueologia na Amazônia Central vista de uma perspectiva da região do lago do Limão. M. S. Thesis, Museu de Arqueologia e Etnologia, Universidade de São Paulo.

Moraes, Claide de Paula, and Eduardo Góes Neves. 2019. "Earthworks of the Amazon." In Encyclopedia of Global Archaeology, 1-13. Cham: Springer International Publishing.

Moran, Emilio F. 1993. Through Amazonian Eyes: The Human Ecology of Amazonian Populations. Iowa City: University of Iowa Press.

Neves, Eduardo Goes. 2016. "A tale of three species or the ancient soul of tropical forests." In Tropical forest conservation: long-term processes of human evolution, cultural adaptations and consumption patterns, p. 229-244. Paris: United Nations Educational, Scientific and Cultural Organization.

--------2013. "Was Agriculture a Key Productive Activity in Pre-Colonial Amazonia? The Stable Productive Basis for Social Equality in the Central Amazon." HumanEnvironment Interactions: Current and Future Directions: 371-388.

--------2008. "Ecology, Ceramic Chronology and Distribution, Long-term History, and Political Change in the Amazonian Floodplain." In Handbook of South American Archaeology, edited by Helaine Silverman and William H. Isbell, 359-379. New York: Springer.

Neves, Eduardo Goes, and Eduardo Kazuo Tamanaha. 2012. “Ocupação Polícroma No Baixo E Médio Rio Solimões, Estado Do Amazonas.” Dissertation, Biblioteca Digitais de Teses e Dissertações da USP.

Neves, Eduardo G., and James B. Petersen. 2006. "Political economy and pre-Columbian landscape transformations in Central Amazonia." Time and complexity in historical ecology: studies in the neotropical lowlands: 279-309.

Nimuendajú Curt. 1924. Os Indios Parintintin Do Rio Madeira. Paris: Au siège de la société des Américanistes de Paris. 
Oliver, José R. 2008. “The Archaeology of Agriculture in Ancient Amazonia.” In Handbook of Landscape Archaeology, edited by Bruno David and Julian Thomas, 185-216. Walnut Creek: Left Coast Press, Inc.

Parsons, J. R. 1972. “Archaeological Settlement Patterns.” Annual Review of Anthropology 1: 127-50.

Patterson, Thomas C. 2008. "A Brief History of Landscape Archaeology of the Americas." In Handbook of Landscape Archaeology, edited by Bruno David and Julian Thomas, 77-84. Walnut Creek: Left Coast Press, Inc.

Prestes-Carneiro, Gabriela, Philippe Béarez, Salvador Bailon, Anne Rapp Py-Daniel, and Eduardo Góes Neves. 2016. "Subsistence fishery at Hatahara (750-1230 CE), a pre-Columbian central Amazonian village." Journal of Archaeological Science: Reports 8:454-462. doi: https://doi.org/10.1016/j.jasrep.2015.10.033.

Pugliese, Francisco, Carlos Zimpel, and Eduardo Góes Neves. 2018. What do Amazonian Shellmounds Tell Us About the Long-Term Indigenous History of South America?

Rapp Py-Daniel, A. 2009. “Arqueologia da Morte no sítio Hatahara durante a fase paredão.” M. S. Thesis, Museu de Arqueologia e Etnologia, Universidade de São Paulo.

Roosevelt, Anna Curtenius. 1999a. "Twelve thousand years of human-environment interaction in the Amazon floodplain." Advances in Economic Botany 13: 371392.

1999b. "The development of prehistoric complex societies: Amazonia, a tropical forest." In Complex Polities in the Ancient Tropical World, edited by Elisabeth A. Bacus and Lisa J. Lucero, pp. 13-33. Archaeological Papers of the American Anthropological Association. No. 9. Washington, D.C. 1991. Moundbuilders of the Amazon: Geophysical Archaeology on Marajo Island, Brazil. San Diego: Academic Press, Inc. 1980. Parmana: Prehistoric Maize and Manioc Subsistence Along the Amazon and Orinoco. New York: Academic Press, Inc.

Roosevelt, A e., R. Housley, L M. Imazio da Silveira, S. Maranca, and R. Johnson. 1991. Eighth millennium pottery from a prehistoric shell midden in the Brazilian Amazon. Science 254:1621-1624.

Roosevelt, A. C, M. Lima da Costa, C. Lopes Machado, M Michab, N Mercier, H Valladas, J Feathers, et al. 1996. "Paleoindian Cave Dwellers in the Amazon: The Peopling of the Americas.” Science 272 (5260): 373-84.

Rostain, Stéphen, and Michelle Eliott. 2012. Islands in the rainforest: landscape management in pre-Columbian Amazonia, New frontiers in historical ecology; $v$. 4. Walnut Creek, CA: Left Coast Press, Inc. 
Sauer, Carl. 1962. Land and Life: A Selection from the Writings of Carl Sauer, edited by J. Leighley. Berkley: University of California Press.

Schaan, Denise Pahl. 2011. Sacred Geographies of Ancient Amazonia: Historical Ecology of Social Complexity. New Frontiers in Historical Ecology, Vol. 3. Walnut Creek, CA: Left Coast Press 2008. "The Nonagricultural Chiefdoms of Marajo Island.” In Handbook of South American Archaeology, edited by Helaine Silverman and William H. Isbell, 339357. New York: Springer.

Schama, S. 1996. Landscape and Memory. London: Fontana Press.

Schmidt, Morgan J., Anne Rapp Py-Daniel, Claide de Paula Moraes, Raoni B. M. Valle, Caroline F. Caromano, Wenceslau G. Texeira, Carlos A. Barbosa, João A. Fonseca, Marcos P. Magalhães, Daniel Silva do Carmo Santos, Renan da Silva e Silva, Vera L. Guapindaia, Bruno Moraes, Helena P. Lima, Eduardo G. Neves, and Michael J. Heckenberger. 2014. "Dark earths and the human built landscape in Amazonia: a widespread pattern of anthrosol formation." Journal of Archaeological Science 42:152-165. doi: https://doi.org/10.1016/j.jas.2013.11.002.

Shepard, Glenn H., and Henri Ramirez. 2011. "“Made in Brazil": Human Dispersal of the Brazil Nut (Bertholletia excelsa, Lecythidaceae) in Ancient Amazonia1." Economic Botany 65 (1):44-65. doi: 10.1007/s12231-011-9151-6.

Smith, Nigel J. H. 1980. "Anthrosols and Human Carrying Capacity in Amazonia." Annals of the Association of American Geographers 70 (4): 553-66. doi:10.1111/j.1467-8306.1980.tb01332.x.

Steward, Julian H (ed.). 1946. Handbook of South American Indians. Bureau of American Ethnology Bulliten 143, 7 vols. Washington D.C.: Smithsonian Institution Press.

Strang, Veronica. 1997. Uncommon Ground: Cultural Landscapes and Environmental Values. Oxford: Berg.

2001. "Of human bondage: The breaking in of stockmen in Northern Australia." Oceania 72: 53-78.

2008. "Uncommon Ground: Landscapes as Social Geography." In Handbook of Landscape Archaeology, edited by Bruno David and Julian Thomas, 51-59. Walnut Creek: Left Coast Press, Inc.

Tilley, Christopher, and Kate Cameron-Daum. 2017. Anthropology of Landscape. London: UCL Press. 
Tilley, Christopher. 2006. "Introduction: Identity, Place, Landscape and Heritage." Journal of Material Culture 11, no. 1-2:7-32.

Turner, Monica G. 2005. "Landscape Ecology: What Is the State of the Science?" Annual Review of Ecology, Evolution, and Systematics 36 (1):319-344. doi: 10.1146/annurev.ecolsys.36.102003.152614.

Walker, John H. 2012. "Recent Landscape Archaeology in South America." Journal of Archaeological Research 20, no. 4:309-355.

-------2011. "Social Implications from Agricultural Taskscapes in the Southwestern Amazon." Latin American Antiquity 22, no 3:275-295.

-------2008. "Pre-Columbian Ring Ditches along the Yacuma and Rapulo Rivers, Beni, Bolivia: A Preliminary Review.” Journal of Field Archaeology 33 no. 4:413-427. DOI: $10.1179 / 009346908791071141$.

Watling, J., J. Iriarte, F. E. Mayle, D. Schaan, L. C. Pessenda, N. J. Loader, F. A. StreetPerrott, R. E. Dickau, A. Damasceno, and A. Ranzi. 2017. "Impact of preColumbian "geoglyph" builders on Amazonian forests." Proceedings of the National Academy of Sciences of the United States of America 114 (8):1868-1873. doi: 10.1073/pnas.1614359114.

Wust, Irmhild, and Cristiana Barreto. 1999. "The Ring Villages of Central Brazil: A Challenge for Amazonian Archaeology." Latin American Antiquity 10 (1):2-23.

Woods, William, Wenceslau Teixeira, Johannes Lehmann, Christoph Steiner, Antoinette WinklerPrins, and Lilian Rebellato. 2009. Amazonian Dark Earths: Wim Sombroek's Vision. London: Springer. 


\title{
CURRICULUM VITA
}

\author{
M. Grace Ellis \\ $\underline{\text { mggimb01@louisville.edu }}$ \\ 1916 Deer Park Ave \# 1 \\ Louisville, KY 40205 \\ (502) 468-8362
}

\section{Education}

2016 - 2019 M.A. in Anthropology, University of Louisville, KY.

2009 - 2013 B.A. in Anthropology, University of Louisville, KY (Lambda Alpha, Cum Laude, GPA 3.5) Minor, History.

\section{Honors and Awards}

2019 Department of Anthropology's Outstanding Graduate, University of Louisville, KY.

2013 Dean's Scholar, University of Louisville, KY (Spring).

2012 Dean's List, University of Louisville, KY (Spring).

2011 Dean's List, University of Louisville, KY (Spring).

2010 Dean's List, University of Louisville, KY (Fall).

\section{Research Experience}

2017 - 2019 Research Assistant, Inquiry into the Origins of Modern Human Distributions (Dr. Jonathan Haws), University of Louisville. Process point cloud data and produce maps of Lapa do Picareiro.

2018 GIS and Remote Sensing Lab Technician, Change and Adaptation in Southern Africa: Climate and Land Systems Dynamics of the Kavango-Zambezi 
Transfrontier Conservation Area (Dr. Andrea Gaughan), Tom “EP” Sawyer Park, Kentucky (6 weeks). Gathered field data and compared seasonal differences in tree crown delineation using UAS derived multispectral point clouds.

2018 Student Instructor, Inquiry into the Origins of Modern Human Distributions (Dr. Jonathan Haws), Lapa do Picareiro, Portugal (5 weeks). Oversaw daily operations of the total station, trained students on total station, developed and wrote a field manual, and aided and trained students in excavation, data collection, artifact cleaning and survey.

2017 - 2018 Research Assistant, Human Responses to late Pleistocene Environmental Change in the Coastal Zone of Portuguese Estremadura (Dr. Jonathan Haws), University of Louisville (3 months). Processed point cloud data and produced maps of two sites in Portugal.

2017

2016

Field Technician, Projeto Tupinambarana (Dr. Anna Browne Ribeiro), Parintins, Brazil (3 weeks). Collected topographic data of riverine ports and mapped the depth and distribution of terra preta at the Macurany site.

Field Technician, Inquiry into the Origins of Modern Human Distributions (Dr. Jonathan Haws), Lapa do Picareiro, Portugal (4 weeks). Assisted in managing the total station and aided in excavation, cleaning artifacts, and general survey.

Field Technician, Inquiry into the Origins of Modern Human Distributions (Dr. Jonathan Haws), Lapa do Picareiro, Portugal (6 weeks). Trained in total station operations and methods of excavation, cleaning artifacts, cataloguing artifacts, and general survey.

2013 - 2014 Guest Services Associate, Frazier History Museum, Louisville, KY (9 months). Interacted directly with museum guests, sold tickets and memberships and assisted in daily operations of the gift shop.

2011 Intern, Conrad-Caldwell House Museum, Louisville, KY (3 months). Managed and updated museum database, maintained permanent exhibits, assisted in curating new exhibits, and helped coordinate volunteers.

\section{Publications}

Under Review Haws, J. A., M. M. Benedetti, J. M. Cascalheira, N. F. Bicho, M. C. Carvalho, B. K. Zinsious, M. G. Ellis and L. Friedl. "Human occupation during the Late Pleniglacial at Lapa do Picareiro (Portugal)." Submitted to Human Adaptations to the Last Glacial Maximum: the Solutrean and its Neighbors, edited by Isabell Schmidt and João Cascalheira. Cambridge Scholars, Newcastle upon Tyne.

Under Review Kolarik, N., M. G. Ellis, A. E. Gaughan and F. R. Stevens. "Seasonal Differences in Tree Crown Delineation Using Multispectral UAS Data and Structure from Motion." Submitted to Remote Sensing Letters. 


\section{Conference Participation}

2019 Ellis, M. G. Anthropogenic Landscapes of Amazonia: A spatial analysis of landscape modification and settlement organization at Macurany, Brazil. Paper to be presented at the Annual Meeting of the Society for American Archaeology, Albuquerque, New Mexico. (Apr 11-14).

2018 Ellis, M. G., A. Browne Ribeiro, F. Stampanoni, and M. Carvalho. Ancient Landscapes of Amazonia: A study of pre-colonial processes and contemporary use at Macurany, Brazil. Poster presented at the Annual Meeting of the SAA, Washington D.C. (April 11-15).

2017 Ellis, M. G. Food Deserts in Louisville, KY. Poster presented at the Graduate Student Council Research Conference, Louisville, KY. (March 25).

\section{Grants}

Graduate Student Research Fund, Graduate Network in Arts and Sciences, University of Louisville, research presentation at the $83^{\text {rd }}$ Annual Meeting for the SAA.

2018 Frederic H. Hicks International Student Travel Award, Department of Anthropology, University of Louisville, research presentation at the $83^{\text {rd }}$ Annual Meeting for the SAA.

2017 Frederic H. Hicks International Student Travel Award, Department of Anthropology, University of Louisville, conference attendance.

2012 Frederic H. Hicks International Student Travel Award, Department of Anthropology, University of Louisville, study abroad in Cusco, Peru.

2012 Richard and Constance Lewis Scholar, University of Louisville, study abroad in Cusco, Peru.

\section{Teaching Experience}

2019 Teaching Assistant, Principles of Archaeology, Department of Anthropology, University of Louisville, Spring.

2018 Teaching Assistant, Principles of Archaeology, Department of Anthropology, University of Louisville, Fall.

2018 Guest Lecturer, "Formation Processes," Principles of Archaeology, Department of Anthropology, University of Louisville, Fall.

2018 Teaching Assistant, Introduction to Archaeology, Department of Anthropology, University of Louisville, Spring. 
2018 Teaching Assistant, Rise of Civilization, Department of Anthropology, University of Louisville, Spring.

2018 Guest Lecturer, “Archaeology in Action,” Introduction to Archaeology, Department of Anthropology, University of Louisville, Spring.

2017 Teaching Assistant, Introduction to Archaeology, Department of Anthropology, University of Louisville, Fall.

2017

Guest Lecturer, “Archaeological Survey,” Introduction to Archaeology, Department of Anthropology, University of Louisville, Fall.

\section{$\underline{\text { Service and Outreach }}$}

2018 - 2019 Vice President, Anthropology Graduate Student Association, University of Louisville.

2018 Outreach to K-12 students, Atkinson Academy, Department of Anthropology at the University of Louisville and the Portland Museum, Louisville, KY. (May 11).

2018 Guest Speaker, "Geospatial Analysis in Amazonia," Archaeological Institute of America's Spotlight on Archaeology, University of Louisville. (March 22).

2018 Volunteer, Annual Speed Ball, Speed Art Museum, Louisville, KY. (March 3).

2018 Secretary, Anthropology Graduate Student Association, University of Louisville.

2017 Outreach to K-12 students, Macurany Community, Parintins, Brazil. (July 3).

2017 Volunteer, Annual Speed Gala, Speed Art Museum, Louisville, KY. (March 4).

2016 Volunteer, Speed Opening Gala, Speed Art Museum, Louisville, KY. (March 5).

\section{$\underline{\text { Professional Development }}$}

2018 Surfer Certification, Core Features II. (December 12).

2018 Voxler Certification, Core Features Training. (August 8).

2017 ESRI Certification, Network Analysis Using ArcGIS. (April 5).

2017 ESRI Certification, Building Models for GIS Analysis Using ArcGIS. (March 1).

2012 International Studies Abroad, Universidad de Salamanca ISA, Cusco, Peru. (5 weeks).

\section{$\underline{\text { Institutional Affiliations }}$}

$2016-2019$ Member, SAA. 
2016 - 2018 Member, Anthropology Graduate Student Association, University of Louisville.

2011 - 2013 Member, Anthropology Student Association, University of Louisville.

2009 - 2013 Member, Spanish Club, University of Louisville.

\section{$\underline{\text { Languages }}$}

Spanish: Intermediate.

Portuguese: Beginner. 